\title{
INTERthesis
}

Revista

Internacional

Interdisciplinar INTERthesis

\section{AQUIFER RECHARGE: EPISTEMOLOGY AND INTERDISCIPLINARITY ${ }^{1}$}

\author{
Vitor Vieira Vasconcelos ${ }^{2}$ \\ Paulo Pereira Martins Junior ${ }^{3}$ \\ Renato Moreira Hadad ${ }^{4}$ \\ Sucharit Koontanakulvong ${ }^{5}$
}

\begin{abstract}
:
The environmental issues related to aquifer recharge and discharge present challenges that require an interdisciplinary approach. This paper reports an epistemological study on the contribution of different fields of knowledge to the research on hydrogeological processes. The study is based on the hypothesis that this dialog is essential to the resolution of current and future environmental problems, including those related to water use. The first proposition is to discuss epistemological and information management approaches that may contribute to a better spatial, qualitative and quantitative characterization of aquifer recharge. Preliminary conceptual models are developed to demonstrate the possibilities of interdisciplinary collaboration to solve the environmental issues presented here. The paper concludes with a discussion of the possibilities of incorporating knowledge on aquifer recharge into environmental and water resources policies.
\end{abstract}

Keywords: Aquifers. Hydrogeology. Epistemology. Environment. Interdisciplinarity.

\footnotetext{
${ }^{1}$ We thank FINEP [Financiadora de Estudos e Projetos (Funding Authority for Studies and Projects)], FAPEMIG [Fundação de Amparo à Pesquisa do estado de Minas Gerais (Minas Gerais Research Foundation)], CNPq [Conselho Nacional de Desenvolvimento Científico e Tecnológico (National Counsel of Technological and Scientific Development)] and CAPES [Coordenação de Aperfeiçoamento de Pessoal de Nível Superior (Coordination for the Improvement of Higher Level Personnel)] for funding the research projects that enabled the elaboration of this paper. This paper was developed in the PhD Graduate program in Crustal Evolution and Natural Resources of the Federal University of Ouro Preto (Universidade Federal de Ouro Preto - UFOP). We thank the Geology Department of the UFOP for hosting this research project.

${ }^{2} \mathrm{PhD}$ Candidate in Geology, UFOP, Ouro Preto, Minas Gerais, Brazil. Consultant in Environment and Sustainable Development of the Legislative Assembly of Minas Gerais, Belo Horizonte, Minas Gerais. E-mail: vitor.vasconcelos@almg.gov.br

${ }^{3} \mathrm{PhD}$ Candidate in Géologie Dynamique. Université Pierre et Marie Curie, LISE / CNRS, France. Full Researcher of the Technological Center Foundation of Minas Gerais (Fundação Centro Tecnológico de Minas Gerais - CETEC-MG). Professor in the Department of Geology of UFOP, Ouro Preto, Minas Gerais, Brazil. E-mail: paulo.martins@cetec.br

${ }^{4} \mathrm{PhD}$ in Computer Science at the Federal University of Minas Gerais (Universidade Federal de Minas Gerais - UFMG), Belo Horizonte, Minas Gerais, Brazil. Professor in the Graduate Program in Geography - Spatial Information Treatment of the Pontifical Catholic University of Minas Gerais (Pontifícia Universidade Católica de Minas Gerais - PUC-Minas). Pro-Rector of the PUC-Minas, Barreiro Campus, Belo Horizonte, Minas Gerais, Brazil. E-mail: rhadad@pucminas.br

${ }^{5} \mathrm{PhD}$ in Agricultural Engineering. Associated Professor of the School of Engineering and head of the Research Unit of Water Systems of the University of Chulalongkorn, Bangkok, Thailand. Association. E-mail: sucharit.k@gmail.com
} 


\section{INTRODUCTION}

The topics of water infiltration into soil, the recharge and discharge of aquifers and the relationship between precipitation and groundwater flow have been addressed by a number of academic networks and communities. The departmental structure of academia often results in research centers that gather professionals with the same academic training, who specialize in a specific problem and therefore provide an expert response (ROCHA, 2003, p. 162-165). For example, there are research groups for aspects of the theme studied here in areas such as hydrogeology (stricto sensu), structural geography, geotechnics, hydrology, agronomy, sanitary engineering, environmental engineering, karst geomorphology, environmental management and urban planning.

Each research center develops techniques in its research projects that are related to different scales of approach and methods of analysis in research contexts that differ in the available human and financial resources and the time devoted to each research project, as well as other characteristics (MARTINS JUNIOR, 2000; SCANLON et al., 2002). This relative heterogeneity of the research groups results in a specialization of the conceptual and theoretical discourse over time (BAUER, 1990, p. 105-110) and, finally, different means of analyzing hydrogeological phenomena.

Parallel to the scientific progress that resulted from the disciplinary approach to knowledge (specialization), academia has recognized the possible benefits that may emerge from a dialogue between the different research centers. This recognition resulted in the valorization of interdisciplinary research. Typically, the interaction between different research areas enables a broader analysis of the issues to be studied (ROCHA, 2003, p. 169-170; ROCHA, 2004, p. 9). In addition, regarding the advancement of scientific knowledge, the exchange between research communities usually enables researchers to advance beyond the paradigms of each specific area through exposure to new approaches to a given problem (FLORIANI, 2004, p. 36; OLIVEIRA, 2005; SIVALAPAN, 2005).

Solving today's environmental problems, which are often related to the management of natural resources, is a clear example of the need for interdisciplinary collaboration. As a means of interdisciplinary integration, Martins Junior (1998) suggests that the fields of knowledge that originate from geoscience be combined in what this author refers to as "Agricultural and Environmental Geosciences" to apply 
interdisciplinary solutions to the sustainable management of a region. A number of environmental and epistemological studies have been performed using this approach (MARTINS JUNIOR, 2006; MARTINS JUNIOR et al., 2006; 2008; 2009; 2010; 2012), which demonstrated how land use management may be aided by a joint analysis of aspects such as aquifer recharge, agricultural suitability and vegetation connectivity as they regard both economic and ecological implications.

However, interdisciplinary dialog is not a challenge-free task. Such dialog is based on a detailed analysis of the conceptual meanings of each of the theoretical bodies of knowledge involved (BAUER, 1990, p. 113-115; FRANCELIN, 2011), which often includes clarifying different interpretations of the same word or expression (MARI, 2005). Transcending the concepts, the possibilities of links between the theoretical configurations and approach paradigms require detailed epistemological study (MARTINS JUNIOR, 2000; OLIVEIRA, 2005). These research efforts are not always easy in the academic and professional environment because they require changes in the custom of only valuing an expert in a particular field of knowledge and considering his/her field as inviolable (ROCHA, 2003, p. 172-178).

Thus, this paper discusses the epistemological aspects related to the possibilities of interdisciplinary dialog on the processes of groundwater circulation, with special emphasis on aquifer recharge. The paper starts with a discussion of the concepts and methods available for the different objects and scales of approach to this process. Then, an interdisciplinary modeling of this knowledge is proposed using diagrammatic and textual models based on information management technologies. The paper concludes with a discussion of how knowledge regarding aquifer recharge may support environmental and water resources policies.

\section{EPISTEMOLOGICAL ISSUES REGARDING OBJECTS, CONCEPTS AND MULTISCALE METHODS}

\section{Epistemological Fields and Conceptual Domains}

The first step in investigating the interdisciplinary theme involved in the study of aquifer recharge is to detail how the academic communities developed different interpretative approaches to solve issues that are important for society. Box 1 shows a general view without intending to provide complete coverage of the fields of R. Inter. Interdisc. INTERthesis, Florianópolis, v.10, n.2, p. 360-409, Jul./Dez. 2013 
knowledge and the studies involved but considering the main axes that resulted in structural advance in these scientific studies.

The semantic drift of concepts used in the communication between the fields of knowledge may mask biases that, when not divergent, at least focus on different aspects. One example is the concept of surface formation, which is important in delineating, in many bodies of knowledge, the object of study with respect to aquifer recharge and discharge. When used in agronomy and geomorphology, the concept of surface formation is related to the layer "composed of decayed material or weathered parent material covering the bedrock - therefore, it encompasses the notions of soil and part of the subsoil" (GUERRA; GUERRA, 2006, p. 284). However, in geology, this term is often used in the field of surficial geology, where it incorporates the interpretation of formation as a category of stratigraphic classification. Thus, this concept emphasizes the correlation between rocks, structures, sedimentary deposits, weathered mantle and other outcropping geological features (JACKSON, 1997).

Box 1 - Epistemological fields of knowledge, research objects and classic questions according to professions and disciplinary specializations.

\begin{tabular}{|l|l|l|}
\hline Research Area & $\begin{array}{l}\text { Scale of the } \\
\text { Research Object }\end{array}$ & Classic Questions \\
\hline Agronomy & Soil profile & $\begin{array}{l}\text { Relationship between soil } \\
\text { structure and water regarding } \\
\text { the availability for plants and } \\
\text { irrigation. }\end{array}$ \\
\hline Geotechnics & Weathered mantle & $\begin{array}{l}\text { Relationship between water } \\
\text { and soil structure regarding } \\
\text { stability or risk for occupation }\end{array}$ \\
\hline Hydrology & $\begin{array}{l}\text { Isotropic (spatially } \\
\text { homogenized) } \\
\text { hydrographic basin }\end{array}$ & $\begin{array}{l}\text { Water balance for the } \\
\text { calculation of water availability } \\
\text { and flood control in projects of } \\
\text { human water supply and } \\
\text { reservoir construction }\end{array}$ \\
\hline $\begin{array}{l}\text { Mining } \\
\text { Engineering }\end{array}$ & $\begin{array}{l}\text { Surface geological } \\
\text { formations }\end{array}$ & $\begin{array}{l}\text { Lowering of the water table for } \\
\text { mining }\end{array}$ \\
\hline Geochemistry & Groundwater flow & $\begin{array}{l}\text { Characteristics of the origin of } \\
\text { water and its contamination }\end{array}$ \\
\hline $\begin{array}{l}\text { Karst } \\
\text { Geomorphology }\end{array}$ & $\begin{array}{l}\text { Route between } \\
\text { dolines, sinks, } \\
\text { cavities and } \\
\text { resurgences }\end{array}$ & $\begin{array}{l}\text { Role of water circulation in the } \\
\text { genesis of the exo- and } \\
\text { endokarst }\end{array}$ \\
\hline Hydrogeology & Aquifer & $\begin{array}{l}\text { Structural delineation of } \\
\text { aquifer-bearing rock systems } \\
\text { to support well drilling and } \\
\text { exploitation }\end{array}$ \\
\hline
\end{tabular}

Incorporating representation models from other fields of knowledge into R. Inter. Interdisc. INTERthesis, Florianópolis, v.10, n.2, p. 360-409, Jul./Dez. 2013 
hydrogeology also demands a number of epistemological adaptations.

For example, the cartography of lineaments, a subfield of structural geology, was developed primarily to analyze the direction and magnitude of tectonic stresses. Nevertheless, in the last decades many studies have attempted to correlate the density, direction and connectivity of lineaments with aquifer characteristics, under the hypothesis that the advance of tectonic stresses, which is related to an increase in the number of faults, will also increase aquifer recharge in anisotropic milieus (FERRIL et al., 2004).

However, Martins Junior et al. (2006) note that for the research to be minimally consistent, it would have to differentiate between the lineaments that correspond to ductile and brittle structures, thus differentiating their roles in the hydrological flow of the aquifer under study. In addition, CETEC (1981) emphasizes that studies that consider only the two-dimensional density of fractures may mask substantially more significant effects related to the spatial heterogeneity in the depth and width of these fractures.

Additionally, the normal, inverse and transcurrent tectonic movements associated with geological faults may cause discontinuities that block the hydrological flow of porous bedding, as noted by Gleenson and Novakowski (2009). An analogous case was observed in the Guarani aquifer in South America, where structural analyses of the Santa Maria and Piramboia Formations by Rosa Filho et al. (2003) and Soares (2008) demonstrated that understanding the movement associated with faults required a review of the preliminary models and calculations of recharge, flow and discharge (ROCHA, 1997), which had been based on the theoretical assumption of continuous porous media.

\section{Scales of Approach to Groundwater Circulation}

The different hydrogeological study methods may also be grouped by their temporal and spatial scales. Regarding the time aspect, Balek (1988, p. 4-6) classifies the approaches into three categories: short-term, seasonal and historical. Each category emphasizes different instruments: (1) the short-term approaches primarily analyze the water flow in the soil profile, (2) the seasonal analysis focuses on the variations in water balance and (3) the historical period (up to thousands of years) attempts to assess the water residence period in the aquifers primarily by R. Inter. Interdisc. INTERthesis, Florianópolis, v.10, n.2, p. 360-409, Jul./Dez. 2013 
isotope analysis.

The variation in the spatial scale of the study objects reflects relevant epistemological implications. When methods employed for small experimental areas are expanded for larger areas, they risk not taking into account spatial heterogeneities, emergent properties and interrelationships between wider-scale processes.

For example, when applying a theoretical construct of a homogeneous soil profile structure to a large tridimensional extension of a specific environment, there is a risk that the variations of complexity due to scale will not be taken into account. Reggiani et al. (2000) propose that when traditional hydrogeological flow equations are applied to hydrographic basins, those equations must consider a system perspective that incorporates the feedback between the processes involved in the water balance and the variations in the pressure of the hydraulic gradient. For this purpose, the authors demonstrate that the emergent properties may be estimated by a thermodynamic approach, including an assessment of the system's entropy.

In another consideration of this subject, Sivalapan (2005) proposes a focus on the identification of patterns, processes and functions at the scale of the larger basins that encompass the different data on and models already available for small basins. This approach would be an alternative to the current strong reductionist approach to research on water resources (at the spatial scale and in disciplinary specialization) and a step toward a more comprehensive theory.

\section{Inter-scale Differences in Hydrographic Basins}

At the hydrographic basin scale of analysis, the assessment of the hydrological and hydrogeological processes of different sub-basins must consider the area and position of the sub-basins in the topographic equilibrium profile because these processes change gradually from upstream to downstream areas.

Smaller sub-basins, which are close to the springs and watershed limits, often have steeper slopes and are more affected by orographic precipitation (TUCCI, 2009, p. 601). These basins are characterized by a rapid response of the concentrated surface runoff to precipitation, and their flow is affected primarily by short-duration convective precipitation (TUCCI, 2009, p. 393). Therefore, many of the flood peaks in these basins are not detected by gauging stations that only measure the flow twice a 
day (NAGHETTINI; PINTO, 2007, p. 8). As for the hydrogeological processes in these sub-basins, the hydraulic gradient conditioned by altitude results in the spatial predominance of areas with a more expressive recharge, even though this typology of discharge is also relevant in the spring sites (MARTINS JUNIOR et al., 2009).

Moving downstream from the top of the hydrographic basin, the recharge and discharge processes tend to reach equilibrium, forming what Souza and Fernandes (2000) refer to as a transmissivity (or transience ${ }^{6}$ ) area. Further downstream, the accumulated discharge of local and regional hydrogeological processes continues to provide an increasingly stable participation of the baseflow in the total flow of the riverbed. The greater the extension of an underground aquifer is, the more important and complex is the research regarding its structural and lithostratigraphic geology, which aims to confidently delimit the tridimensional outline and the anisotropy of the porous, fractured and karst media, as well as the distinction between the local and regional hydrogeological flows.

In larger-sized basins, the frontal precipitation has the greatest effect on recharge and flow. Additionally, the influence of this precipitation depends on whether the instability front moves from upstream to downstream or in the opposite direction (TUCCI, 2009, p. 393). In addition, the occurrence and extension of flood plains and the accumulated effect of friction along the hydraulic course of the riverbed affect the analyses of flow and recharge (TUCCI, 2009, p. 601) by the seasonal variation in riverbed siltation as opposed to lowering (CHEVALLIER, 2009, p. 512-513) and by cushioning the flood waves (SILVEIRA, 2009, p. 44). Such phenomena also result in sequential evapotranspiration and infiltration at marginal lakes and hydromorphic alluvial soils (TUCCI, 2009, p. 249).

Therefore, studies performed in only one isolated basin may result in uncertainties regarding their application in other basins, especially at other scales of approach. Sivalapan (2005) emphasizes that the progress of hydrological and hydrogeological science demands a methodological reorientation such that studies on hydrographic basins are conducted on a system of nested basins whenever possible. In this way, the evaluation of a hydrogeological process would have to be

\footnotetext{
${ }^{6}$ Souza and Fernandes (2000) use the classification of Transmissivity Area, which is located between the Recharge and Discharge Areas. However, the concept of transmissivity is already used in a narrower context, as a hydraulic parameter in aquifer tests. However, Souza and Fernandes (2000) employ the term Transmissivity Zone to refer to a more general interpretation of the functioning of the aquifer systems. To avoid imprecision in the interpretation, we suggest that it is more practical to use the term Transience Area instead of Transmissivity Area.
}

R. Inter. Interdisc. INTERthesis, Florianópolis, v.10, n.2, p. 360-409, Jul./Dez. 2013 
measured at different points throughout the hydrographic basin, while subdividing the data by sub-basin to assess how this process varies with the increase at the basin scale.

\section{Soil Drainage as Object of Interdisciplinary Dialog}

The issue of specialization and of the possibilities of interdisciplinary dialog may also be addressed from the variables and attributes measured in the research projects. When interpreting the water flow in porous media, the variables used by the different academic communities clearly show how the same subject may be approached from different ways. Pedology (Soil Science, understood both as the basic soil survey and as the study of agricultural suitability) and slope profile analysis (employed with different, but complementary, focuses in Geotechnics and Structural Soil Analysis) comprise such an example, and an approximation of their concepts is shown in Box 2. In this box, each column corresponds to a disciplinary approach (Soil Survey, Agricultural Suitability and Slope Profile Analysis), whereas the arrows show the interconnections among the variables studied in each of these approaches. Thus, Box 2 shows the possibility of interdisciplinary dialog between the theoretical matrices as a way of contributing to a deeper understanding of their study objects.

Other concepts are potentially of interest when the relationship among soils, plant cover and aquifer recharge is considered, even if these concepts are not always directly related to aquifer recharge in conventional academic studies. Examples are the concepts of moisture profile and capillary tension, as well as the attributes described in the center column of Box 2. As phenomena such as interception, evapotranspiration, infiltration and surface runoff are influenced by the vegetation type, the aspect of soil water availability may transfer to the study of aquifer recharge concepts, methods and theories originated from the academic fields of agricultural suitability and landscape ecology (SCHRÖDER, 2006; MARTINS JUNIOR et al., 2010).

R. Inter. Interdisc. INTERthesis, Florianópolis, v.10, n.2, p. 360-409, Jul./Dez. 2013 
Box 2 - Comparison between the variables used in pedology, agricultural suitability and slope profile analysis, based on Martins Junior et al. (2010, p. 91).

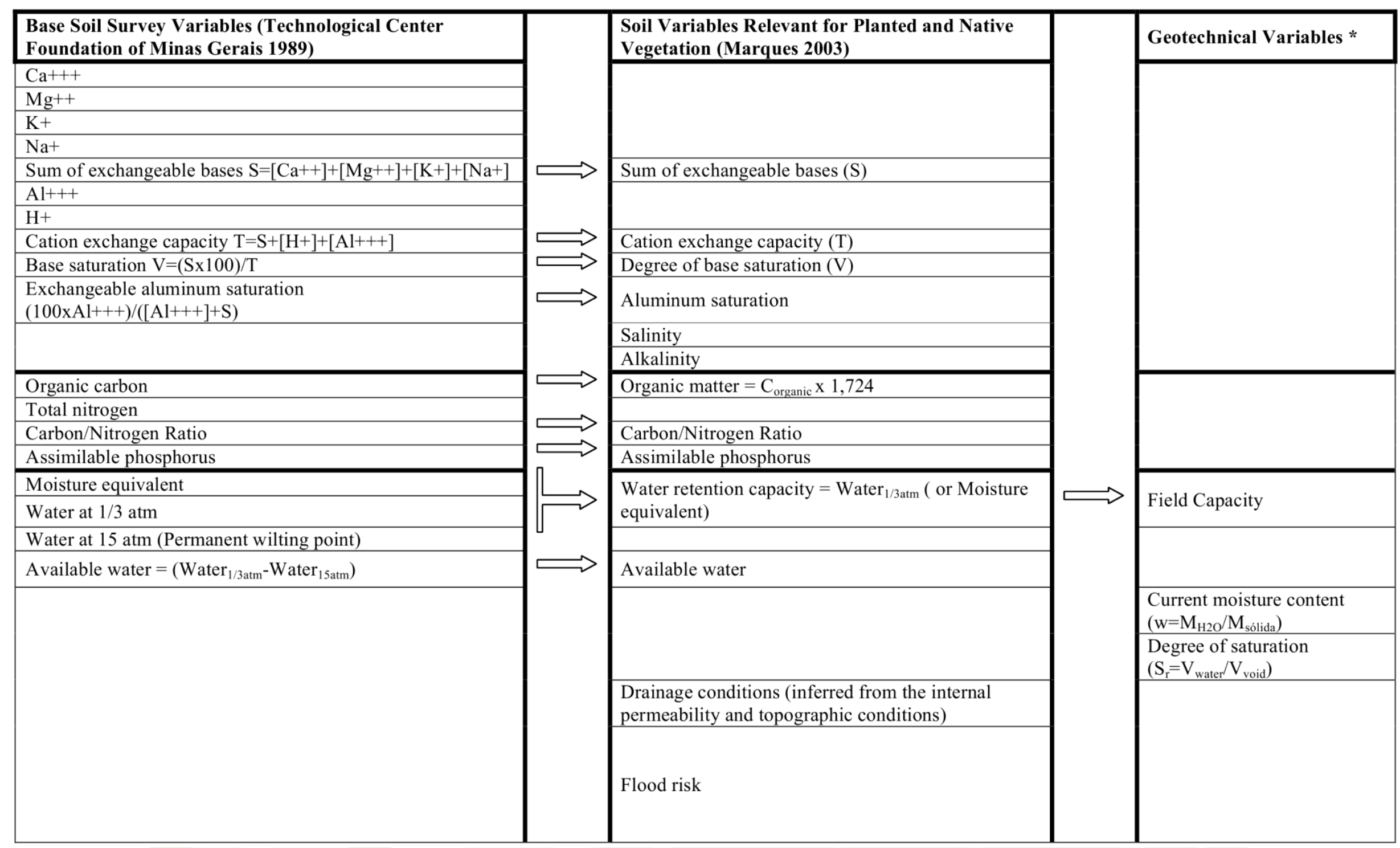

R. Inter. Interdisc. INTERthesis, Florianópolis, v.10, n.2, p. 360-409, Jul./Dez. 2013 
Box 2 - Continuation

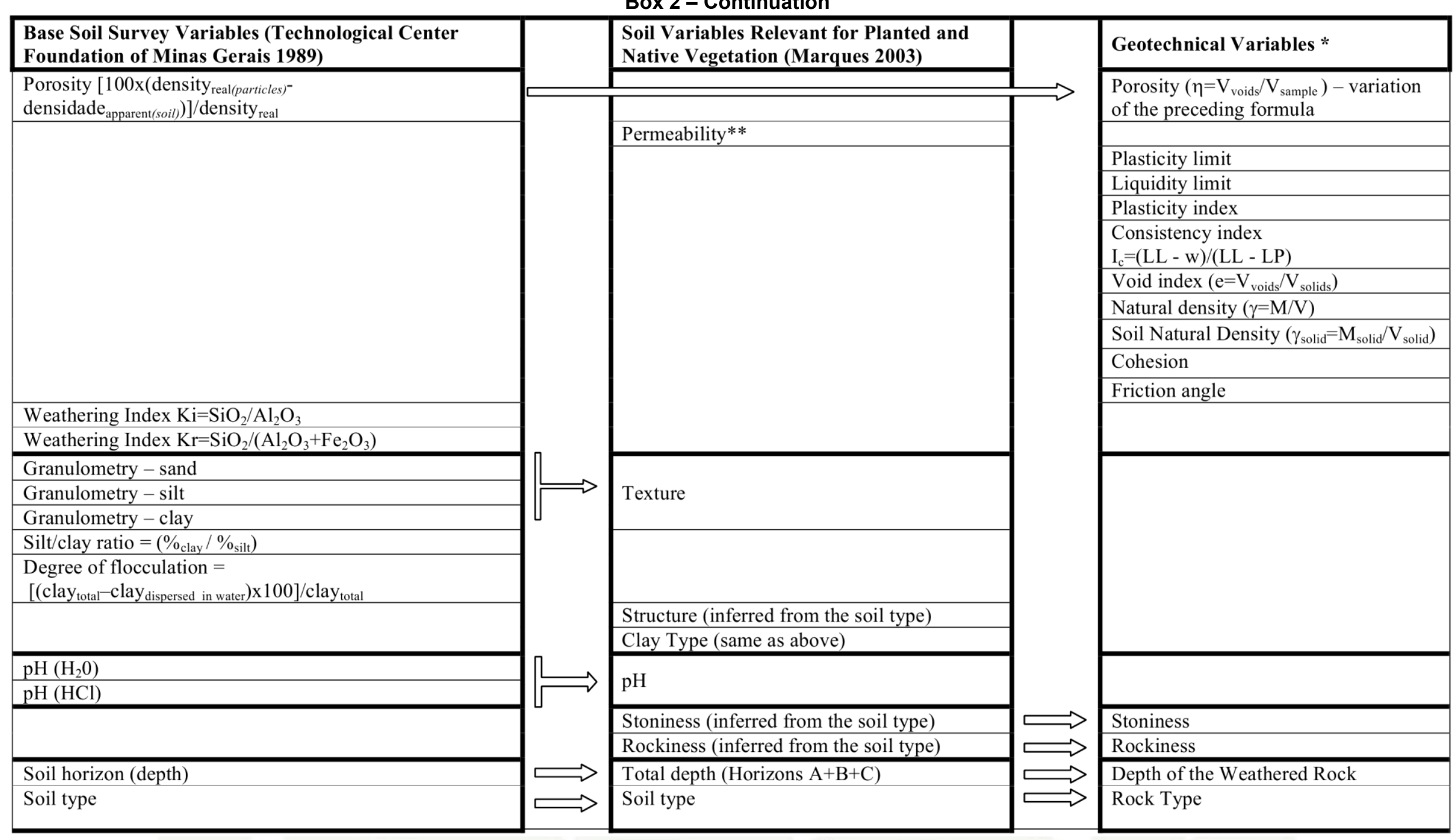

R. Inter. Interdisc. INTERthesis, Florianópolis, v.10, n.2, p. 360-409, Jul./Dez. 2013 
Observations regarding Box 2:

* applicable to soils (Structural Soil Analysis and Geotechnics) and to rocks bearing aquifer reservoirs.

** the impermeable terrain presents problems to agriculture and is inferred from the profile's internal characteristics (underground impermeable horizons, or 2:1 clays in plain topography or depressions) and external characteristics, such as the general topography of depressions. This requires the observation of the terrains of marginal lakes, of flood plains, of shallow depressions and of hydromorphic soils in general.

When recovering principles of Structural Soil Analysis, Queiroz Neto (2000), Santos (2000) and Juhász et al. (2006) demonstrate the limitations of conventional soil studies that only examine the vertical variation in the soil profile without emphasizing the horizontal and sub-horizontal processes, such as slope, the subsurface lateral flow of solutions and free aquifer runoff in the soil's saturated zone. Regarding this topic, when interpreting soil within the context of slope and hydrographic basin, Reggiani et al. (2000, p. 1861) emphasize the necessity of performing new studies that involve the circulation of water as vapor, from the saturated and unsaturated zones to the surface (considered as soil evaporation), while taking into account the vertical heterogeneity of the soil horizons. This author also notes the necessity of correlating on wider spatial scales attributes of slope, hydraulic gradient and soil evaporation (REGGIANI et al. 2000, p. 1856).

Drainage (or internal redistribution) is an attribute used in soil surveys that is of interest for soil water flow. The concept of drainage refers to the dynamics of water spread in the soil profile in response to the gravity and pressure gradients after the infiltration phenomenon has ceased (SILVEIRA et al., 2009, p. 356). This variable was initially formulated to characterize whether the soils would display a reaeration ability (by water runoff and desaturation) after precipitation events (including irrigation) so not to hamper the growth of agricultural crops.

Adopted as a mapping attribute by the Brazilian Society of Soil Science (SANTOS et al., 2005), the cartographic information related to soil drainage may transcend agricultural suitability and help to indicate the recharge potential of underlying aquifers. Soil drainage has also been incorporated into soil mapping in England using the Hydrology of Soil Types (HOST) method (BOORMAN et al., 1995) and in the USA using the soil hydrologic groups (USDA, 2001). As a general characteristic that emphasizes the result of water circulation, the concept of drainage 
may encompass the processes that result from parameters such as permeability, structure and conductivity but on a wider scale that includes the storage capacity of the soil profile, the variation in the water table and the flow processes in the hydrogeological basin.

\section{Specialization and Transdisciplinary Dialog in the Study of Aquifer Recharge}

Reanalyzing Box 1 and the previous considerations, it must be acknowledged that hydrogeology and hydrology have become, in many research centers, areas in which the knowledge produced by other academic communities has converged. Therefore, these convergence areas have had the opportunity to develop a valuable interdisciplinary nature. However, the opposite route is also necessary in order that scientific progress in the aquifer recharge field, which has been achieved by hydrogeology and hydrology, may be applied by other fields of knowledge that contend with environmental and agricultural issues. This issue will be addressed in later sections of this paper.

The need for internal specialization by hydrogeology (including hydrology) research teams has resulted in specialized technical and scientific knowledge domains. One noteworthy specialization is that of the mathematical-statistical modeler, in contrast to the professional who interprets field data and systematizes them in geographic information systems.

In large-scale research projects, these functions are often performed by different professionals or different research teams (HOLTSCHLAG, 1997, p. 3; FLYNN; TASKER 2004, p. 24). In such projects, the field geoprocessing team transfers the measured and processed environmental variables to the mathematicalstatistical modelers. The modelers then construct the relevant models by contrasting these spatial input variables with the variables related to water and hydrogeological measurements.

Sui and Maggio (1999) and Rosa (2002, p. 44) demonstrate that this specialization is also observed in software development, in which the programming blocks related to hydrology and cartographic information systems (including the programming blocks within the same software) are usually transferred to different specialized professionals. These authors demonstrate that in these projects, each

team uses substantially different epistemological and ontological approaches to 
programming.

\section{Conceptual and Empirical Hydrogeological Models}

Transcending the different approaches used by different departments, the theoretical constructs may also be analyzed using more general epistemological models. Novaes (2005, p. 9-15) differentiates between two categories of hydrogeological and hydrological models: conceptual and empirical.

The functions of the conceptual models are constructed based on concatenated observations of the physical processes described in the literature regarding the hydrogeological cycle (NOVAES, 2005, p. 11-12). The methodological issue faced by these models is that given their need for a relatively large number of variables and measurements in space, their application in larger spatial dimensions becomes more difficult. This difficulty is even larger in developing countries, which do not possess sufficiently detailed hydrological and environmental databases (SIMMERS, 1988, p. 7). Given the difficulty of obtaining the parameters required by these models, they are often based on estimates, which diminishes the degree of certainty of the models (NOVAES, 2005, p. 12).

Another criticism is that a large number of conceptual models are formulated and calibrated based on the environmental processes of the temperate countries of the Northern Hemisphere, which results in significant errors when these models are applied to other contexts, such as tropical areas (ANDRADE et al., 2006, p. 24). The required calibration of these models to the context of tropical basins may distort the original models beyond acceptable limits. In addition, this practice prevents learning from patterns that could potentially emerge from new observations in these basins (SIVALAPAN, 2005).

Empirical models, in contrast, begin with the cause-and-effect relationships between the input and output variables and then calibrate functions that indirectly simulate the physical processes involved (TUCCl, 2002), in a black-box-type approach. Typically, the models involve multivariate analyses, such as neural networks and principal components analysis, applied to stochastic hydrological data.

A word of caution by Collischonn and Tucci (2001) regarding the empirical models is that by proposing that the integration of all of the hydrogeological processes of a basin be represented by one output variable, i.e., water flow (surface 
or groundwater flow, or less often baseflow), the calibration process results in infinite combinations of the variables that plausibly pertain to hydrogeological basins, which produces uncertainties in parameter definitions. Such uncertainties are potentiated by the frequent spatial correlation among environmental variables, as a result of the joint bio-pedo-morpho-litho-climatic formation history of each local ecosystem (RETALLACK, 2008).

To reduce the number of uncertainties found in the empirical models, Clarke (2009, p. 667-668) recommends that parameters be included parsimoniously. Therefore, it is important to use quantitative statistical methods to assess whether each new variable should be included. This economy of constructs may be performed by using variables that are correlated to systemic spatial variables, such as the area of the hydrographic basin, altitude position in the equilibrium profile and evapotranspiration. However, the use of a smaller number of variables not only results in more spatially homogeneous (simplified) results but also complicates inferences regarding the role played by different environmental parameters in the given hydrogeological process.

\section{INTERDISCIPLINARY MODELING OF AQUIFER RECHARGE AND DISCHARGE}

This section proposes a textual and diagrammatic modeling approach that encompasses the different information originating from the knowledge domains involved in the environmental analysis of aquifer recharge and discharge. This model is intended to provide an integrated and epistemologically consistent view of the encompassed knowledge. The computational formalization of the knowledge on aquifer recharge presented below consists of the work of the CETEC-MG (Fundação Centro Tecnológico de Minas Gerais [Technological Center Foundation of Minas Gerais]) and the UFOP (Universidade Federal de Ouro Preto [Federal University of Ouro Preto]) joint research team, which includes this paper. The studies of this research team were documented by Martins Junior (2006; 2007) and Martins Junior et al. (2009) and synthesized by Vasconcelos et al. $(2005 ; 2011)$ and Martins Junior et al. (2006; 2008; 2010).

This effort is a first step to assess information that may be structured as databases for cartography, geographic information systems, logical algorithms, mathematical and statistical models, and tridimensional diagrams and information, as 
well as knowledge regarding the explicit textual content or the tacit knowledge of the researchers. The formalization of the knowledge modalities and their logical typologies are crucial in defining the possibility of using information models and tools to solve the problems related to groundwater circulation.

The modeling was performed by stages based on information science methods, such as conceptual maps (SOWA; MOULIN; MINEAU, 1993), SisORCI/SisARCQ (MARTINS JUNIOR et al., 2006; 2007), CommonKADS (knowledge acquisition and documentation structuring) (SCHREIBER et al., 1999), Unified Modeling Language (UML) (BOOCH et al., 1999) and knowledge representation (SOWA, 2000). The conceptual models introduced here were elaborated based on advice from expert researchers and review of the technical literature. The models are not intended to provide complete coverage of the fields of knowledge but aim to represent the connections that were deemed most relevant.

Box 3 presents a preliminary integration that indicates how the different fields of knowledge may contribute to the study of aquifer recharge areas. The box uses aquifer recharge zone (ARZ) and precise recharge area (PRA) as defined by Martins Junior et al. (2006, p. 652). An ARZ corresponds to an area in which infiltration plays a significant role in the hydrogeological cycle. Such areas are clustered geographically based on pedological, geomorphological and lithostratigraphic studies and recognized on a regional scale. PRAs may be recognized at a more detailed scale within the ARZ context and therefore require more comprehensive studies that include the delimitation of the aquifers and the groundwater flows.

Using the method of interdisciplinary matrices (MARTINS JUNIOR, 2006), Box 3 facilitates the visualization of how the different disciplinary approaches may interact in an articulated manner, thus increasing the knowledge on a given environment and revealing previously implicit or unnoticed correlations. This method consists of listing (in the rows and columns) the different knowledge areas and approaches. The potentially interdisciplinary and transdisciplinary concepts, objects and relationships are emphasized in the cells that correspond to the intersection between rows and columns (VASCONCELOS et al., 2005). This method was also used in the elaboration of Box 4, with the goal of better examining the possibilities of the interdisciplinary integration of the environmental issues related to aquifer discharge and recharge.

Subsequently, Box 4 is expected to enable grouping the interdisciplinary topics 
related to hydrogeology, environmental studies and land use by defining their axes of interdisciplinary integration. According to Martins Junior et al. (2008), such axes arise largely from the spatial topographic connections, as well as from the topological connections between the environmental systems and the fields of knowledge involved. Box 4 shows potential pathways for the use of the parametric variables and those variables related to measurable processes. The aim is to model the ideal conditions for land use by means of the "permission $x$ impediments $x$ specific precautions" approach. 
Box 3 - Topics related to the specialist scientific fields and to the central issues of land use in ARZs and PRAs. Adapted from Martins Junior et al. (2010).

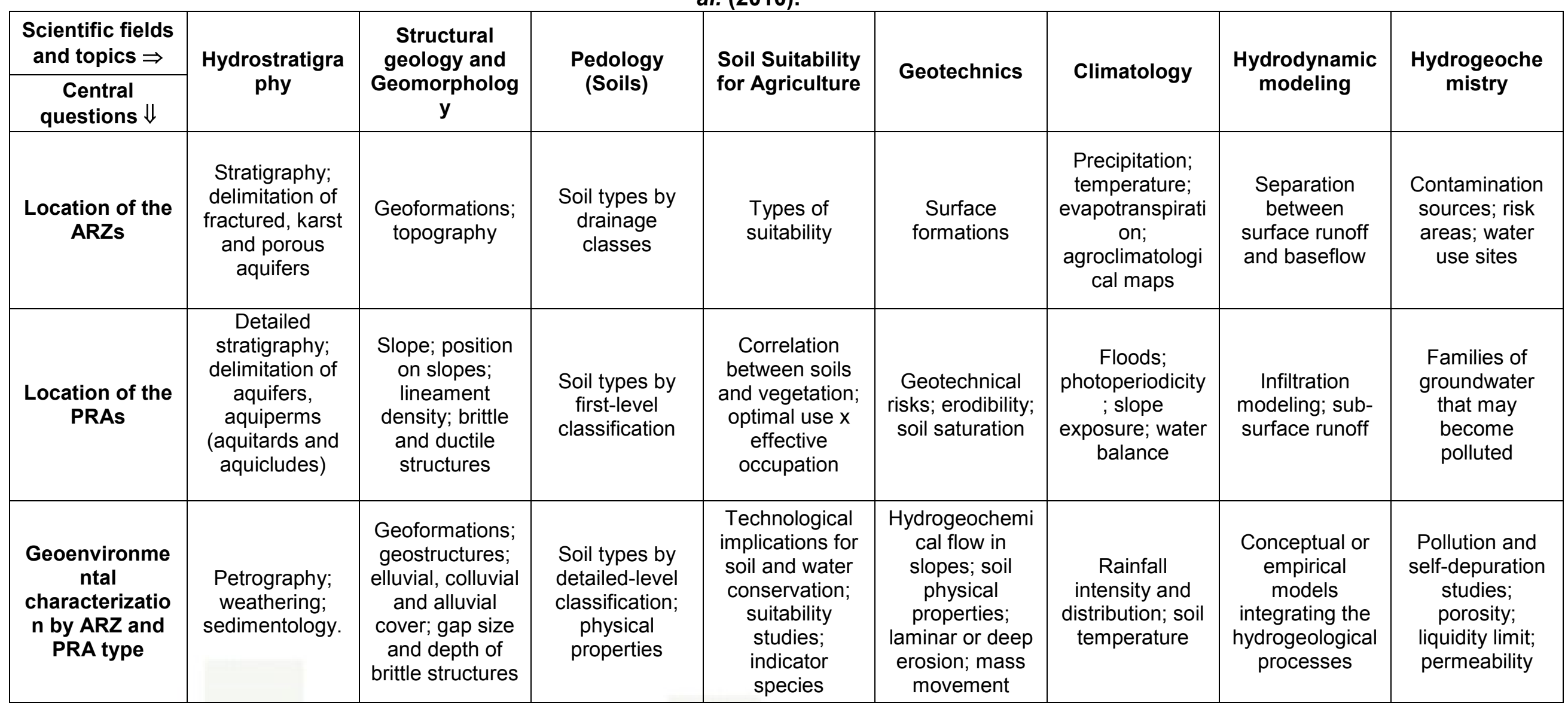

Note: The location of the PRAs considers the attributes listed above for the ARZs plus the attributes described in the corresponding row of Box 3. Similarly,

the geoenvironmental characterization by ARZ and PRA type incorporates the previously mentioned variables and adds the details provided in the corresponding row. 
Box 4 - Groups of variables appropriate to integrating the interdisciplinary concepts applicable to the relationships hydrogeological processes $x$ soil use type $x$ environmental conservation. Adapted from Martins Junior et al. (2008).

\begin{tabular}{|c|c|c|c|c|c|c|c|}
\hline $\begin{array}{l}\text { Groups of } \\
\text { variables }\end{array}$ & $\begin{array}{c}\text { Hydrology / } \\
\text { Hydrogeology }\end{array}$ & Geology & Geomorphology & $\begin{array}{l}\text { Pedology } \\
\text { (Soils) }\end{array}$ & Botany & Agronomy & Geotechnics \\
\hline $\begin{array}{l}\text { G } 1 \text { - Fluvial } \\
\text { environments }\end{array}$ & Specific subsurface flow & $\begin{array}{l}\text { Quaternary detritic } \\
\text { alluvial deposits }\end{array}$ & $\begin{array}{l}\text { Minor, major and } \\
\text { flood riverbeds. }\end{array}$ & $\begin{array}{c}\text { Hydromorphic } \\
\text { soils; alluvial } \\
\text { neosols }\end{array}$ & Riparian forests & Irrigation & \\
\hline $\begin{array}{l}\text { G } 2 \text { - Topologic } \\
\text { and topographic } \\
\text { correlations for } \\
\text { aquifer recharge } \\
\text { and discharge }\end{array}$ & $\begin{array}{l}\text { Drainage network; } \\
\text { surface runoff after rain; } \\
\text { infiltration; surface } \\
\text { baseflow; } \\
\text { evapotranspiration. }\end{array}$ & $\begin{array}{l}\text { Porous formations; } \\
\text { permeable brittle } \\
\text { structures }\end{array}$ & $\begin{array}{l}\text { Cartography of } \\
\text { the various } \\
\text { geoformation } \\
\text { types }\end{array}$ & $\begin{array}{l}\text { Cartography of } \\
\text { the various soil } \\
\text { types }\end{array}$ & $\begin{array}{c}\text { Vegetation } \\
\text { formations; } \\
\text { ecosystems; } \\
\text { phytogeography; } \\
\text { phytosociology }\end{array}$ & $\begin{array}{l}\text { Areas of iso- } \\
\text { suitable soils; } \\
\text { soil drainage }\end{array}$ & $\begin{array}{l}\text { Geotechnical risks; } \\
\text { porosity; void index; } \\
\text { moisture content, } \\
\text { natural density; } \\
\text { degree of } \\
\text { saturation }\end{array}$ \\
\hline $\begin{array}{c}\text { G } 3 \text { - Water } \\
\text { quality }\end{array}$ & $\begin{array}{l}\text { Recharge zones; } \\
\text { hydraulic gradient }\end{array}$ & $\begin{array}{l}\text { Lithostratigraphy; } \\
\text { structural modeling; } \\
\text { geochemical } \\
\text { signature } \\
\end{array}$ & & & Buffer zones & $\begin{array}{c}\text { Infiltration of } \\
\text { agricultural input }\end{array}$ & \\
\hline $\begin{array}{c}\text { G 4-Resurgence } \\
\text { typology }\end{array}$ & Flow in springs & $\begin{array}{l}\text { Rock attitudes; } \\
\text { resurgences from } \\
\text { fractures }\end{array}$ & $\begin{array}{l}\text { Slope models for } \\
\text { resurgences }\end{array}$ & & $\begin{array}{l}\text { Hydrophytic and } \\
\text { hygrophytic } \\
\text { vegetation }\end{array}$ & $\begin{array}{c}\text { Irregular } \\
\text { occupation of } \\
\text { permanent } \\
\text { preservation } \\
\text { areas around } \\
\text { springs } \\
\end{array}$ & Siltation \\
\hline $\begin{array}{l}G 5 \text { - Seasonal } \\
\text { analyses }\end{array}$ & $\begin{array}{c}\text { Surface and } \\
\text { underground circulation } \\
\text { time; climatic cycles }\end{array}$ & & $\begin{array}{c}\text { Karst } \\
\text { hydrogeological } \\
\text { cycles }\end{array}$ & & $\begin{array}{c}\text { Cycles and } \\
\text { seasonality of plant } \\
\text { in general }\end{array}$ & $\begin{array}{c}\text { Cycles and } \\
\text { seasonality of } \\
\text { domestic plants }\end{array}$ & $\begin{array}{l}\text { Geotechnical risks } \\
\text { during extreme } \\
\text { climatic events }\end{array}$ \\
\hline G 6-Water use & $\begin{array}{l}\text { Flow maintenance; } \\
\text { recession coefficient; } \\
\text { Q7,10 }\end{array}$ & Well prospection & & & $\begin{array}{l}\text { Dependency on } \\
\text { ecological water } \\
\text { output }\end{array}$ & $\begin{array}{c}\text { Optimization } \\
\text { between } \\
\text { consumption and } \\
\text { recharge in } \\
\text { irrigation } \\
\end{array}$ & \\
\hline $\begin{array}{l}\text { G } 7 \text {-Soil } \\
\text { degradation }\end{array}$ & & & $\begin{array}{c}\text { Laminar or deep } \\
\text { erosion }\end{array}$ & $\begin{array}{l}\text { Universal soil } \\
\text { loss }\end{array}$ & $\begin{array}{l}\text { Soil-stabilizing } \\
\text { vegetation }\end{array}$ & $\begin{array}{l}\text { Agricultural soil } \\
\text { conservation } \\
\text { techniques }\end{array}$ & $\begin{array}{c}\text { Friction angle, } \\
\text { plasticity and } \\
\text { liquidity limits, } \\
\text { cohesion }\end{array}$ \\
\hline
\end{tabular}

R. Inter. Interdisc. INTERthesis, Florianópolis, v.10, n.2, p. 360-409, Jul./Dez. 2013 
Figure 1 shows an ontological diagram of the environmental issues related to aquifer recharge in a simple hierarchical multi-perspective (SHriMP) structure (STOREY et al., 2002) created using the Protégé software. Ontology corresponds to the network of entities and processes by which the subjects and communities organize theories and assumptions from culture in the broad sense to academic knowledge. Generally, to study ontologies is to define categories for objects that exist within the same domain (ALMEIDA; BAX, 2003) and therefore to create an explicit specification of a concept (CORAZZON, 2002).

The SHriMP ontological diagram presents an efficient approach to detailing classes and subclasses of entities. The visualization of classification systems is an important step for future modeling studies that will be more accessible to the programmer, such as the Unified Modeling Language (UML) (BOOCH et al., 1999). In addition, Protégé is practical because it exports directly to the Ontology Web Language (OWL) (SMITH; WELTY; McGUINNESS, 2004).

One limitation of ontological diagrams is that they do not enable an efficient visualization of conceptual topics. Additionally, they do not indicate the relationships between the entities. Therefore, concept maps are used as a complementary instrument. Concept maps may be understood as structures, diagrams or graphics used to represent the way a subject understands and learns about a given subject (LIMA, 2004). Although these maps do not explicitly represent a term's semantic content, they may be a powerful instrument to transmit a semiotic diagram that will be more efficient in recovering information and building knowledge.

In addition, concept maps aim to support the learning process (LIMA, 2004) by indicating the interrelationship between concepts and the interdisciplinary view. Starting from a universe of information, the concept map helps to concatenate ideas and to produce a more ample and systemic view. Thus, the concept map enables the acquisition and transmission of knowledge by making it easier to perceive contradictions, paradoxes and flaws in the organized content.

Nevertheless, the last decade has seen advances in the programming of systems for the web that offer new possibilities that transcend the simple, twodimensional, static representation of concept maps. Current capabilities of graphical manipulation, language integration, hyperlinks and databases enable the transformation of concept maps into knowledge systems, in which the user may investigate the connections and access specific content according to his or her 
interest.

To take advantage of these technical possibilities, Martins Junior (2007) proposed a new method termed 'Organograma de Rodas de Correlação e Impactos' [Wheel Charts for Correlation and Impacts] (ORCI). ORCI is integrated into a web system formerly known as SisORCl and currently referred to as SisARQC. Therefore, the use of $\mathrm{ORCl}$ organograms for knowledge architecture may be understood as an innovation of the concept maps method. Figure 2 shows the $\mathrm{ORCl}$ developed for the subject of aquifer recharge.

The next step in the logical formalization of knowledge consists of UML modeling using the CommonKADS method (SCHREIBER et al., 1999). More detailed information regarding this line of research in knowledge engineering and CommonKADS for aquifer recharge may be found in Martins Junior et al. (2009) and Martins Junior et al. (2006; 2010). A number of the products developed are presented here to focus on the possibilities of database organization, specifically the class diagrams that describe the primary entities and relationships that pertain to the aquifer recharge domain (Figures 3 and 4 ) and to the procedural aspects of aquifer management (the activities diagram) (Figure 5). 


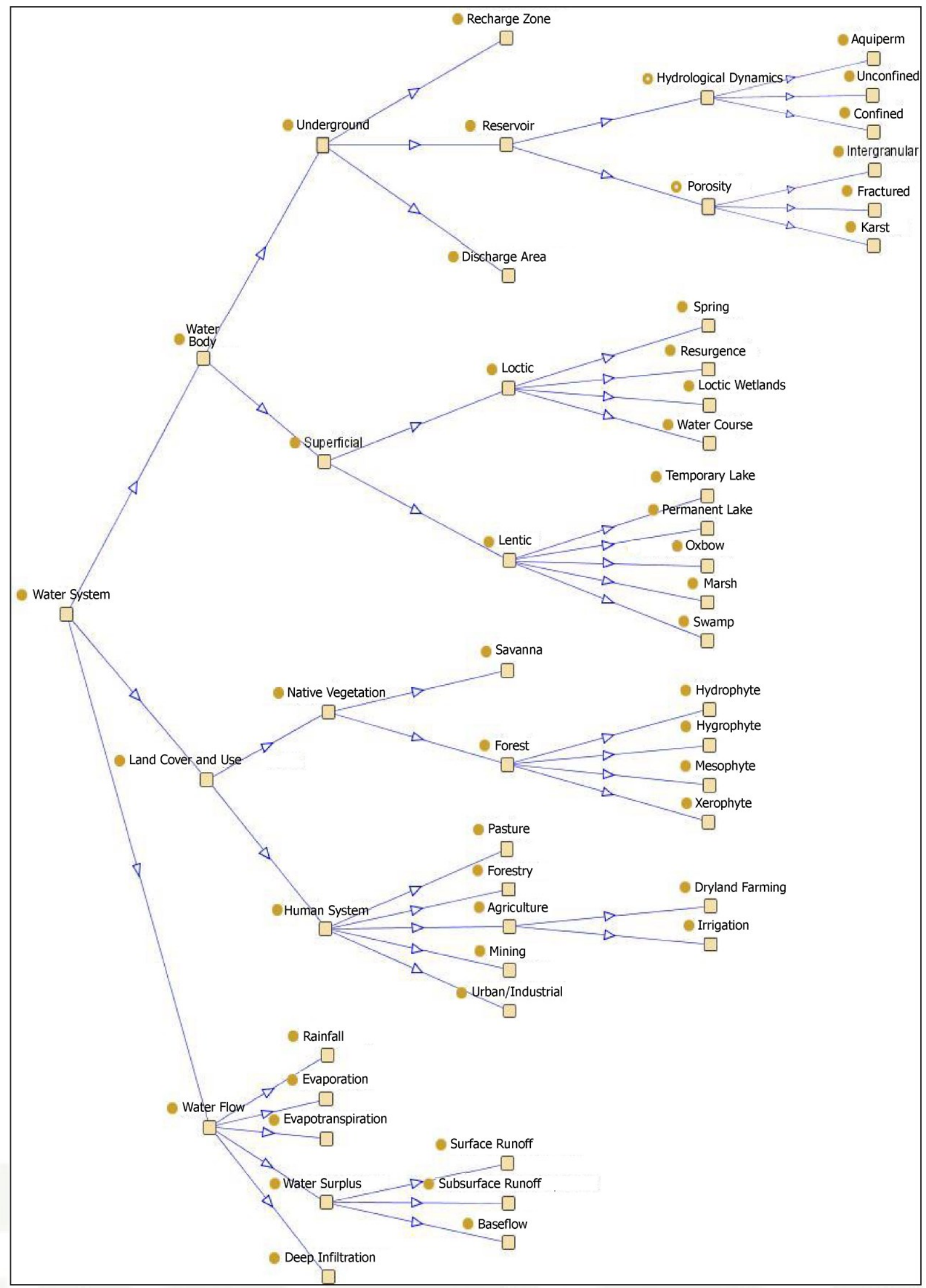

Figure 1-Ontological graph of the structure of the system and subsystems used for aquifer management in a SHriMP reference visualization using the Jambalaya manipulation platform (Storey et al. 2001) and Protégé software. The term aquiperm encompasses aquitards and aquicludes. Source: Translated from Vasconcelos et al. (2011).

R. Inter. Interdisc. INTERthesis, Florianópolis, v.10, n.2, p. 360-409, Jul./Dez. 2013 


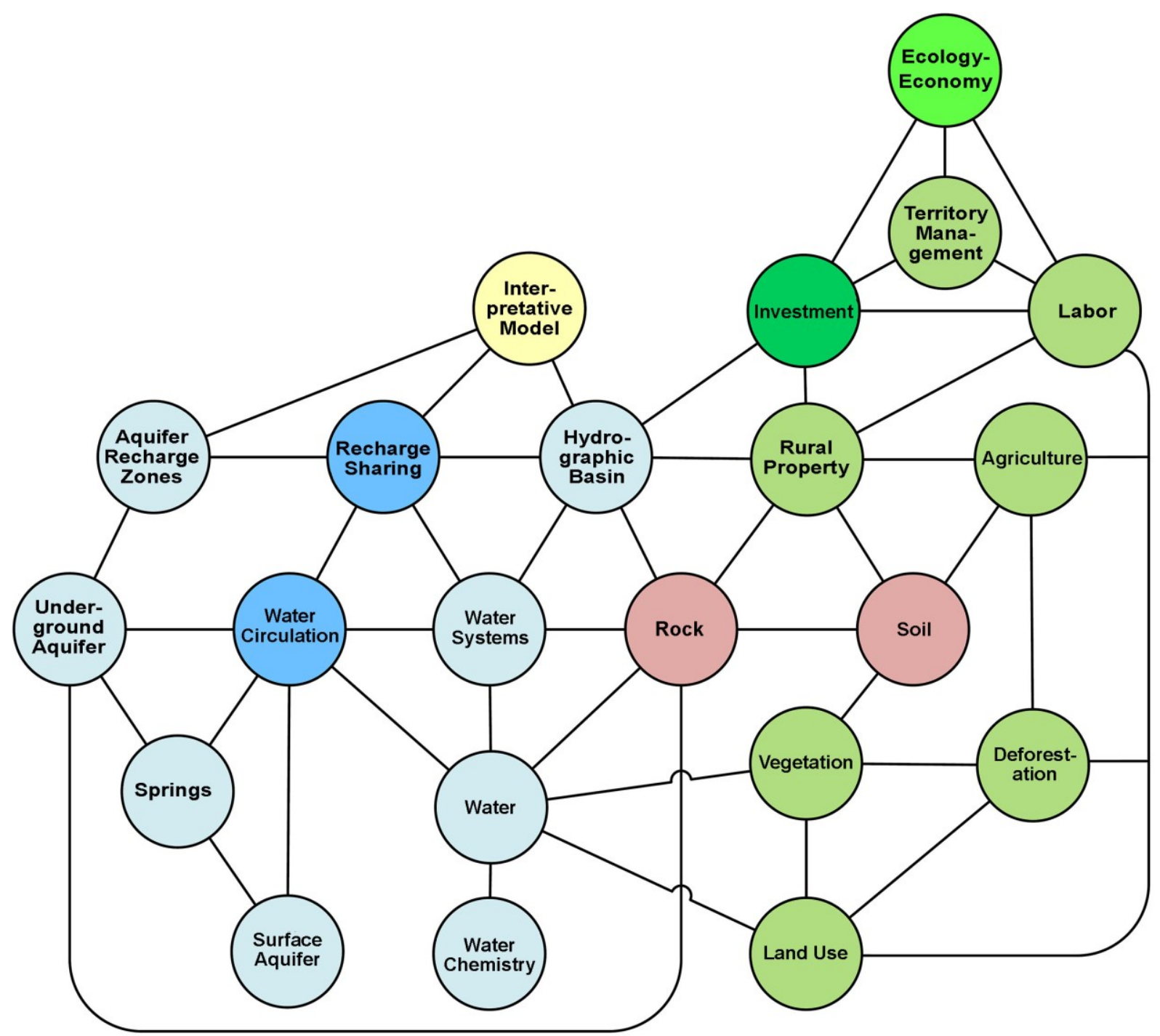

Relationships between the color shades of the content wheels and the phenomena encompassed by the ORCl organogram of ARZs:

\begin{tabular}{|l|l|l|}
\hline \multicolumn{2}{|c|}{ Tone } & \multicolumn{1}{c|}{ Related Phenomena } \\
\hline & Light blue & Water systems \\
\hline & Dark blue & Dynamic water processes \\
\hline & Pink & Rocks and weathering mantle \\
\hline & Light green & $\begin{array}{l}\text { Processes related to land cover and } \\
\text { use }\end{array}$ \\
\hline & Other green & Economic and financial systems \\
\hline
\end{tabular}

Figure 2 - An ORCl organogram for ARZs. There is no hierarchy in the ORCI organogram. Instead, there are sequential, parallel and simultaneous relationships. The relationships may be, e.g., conceptual, systemic or pertaining to sensitivity.

Source: Translated from Martins Junior et al. (2009); Vasconcelos et al. (2011). 


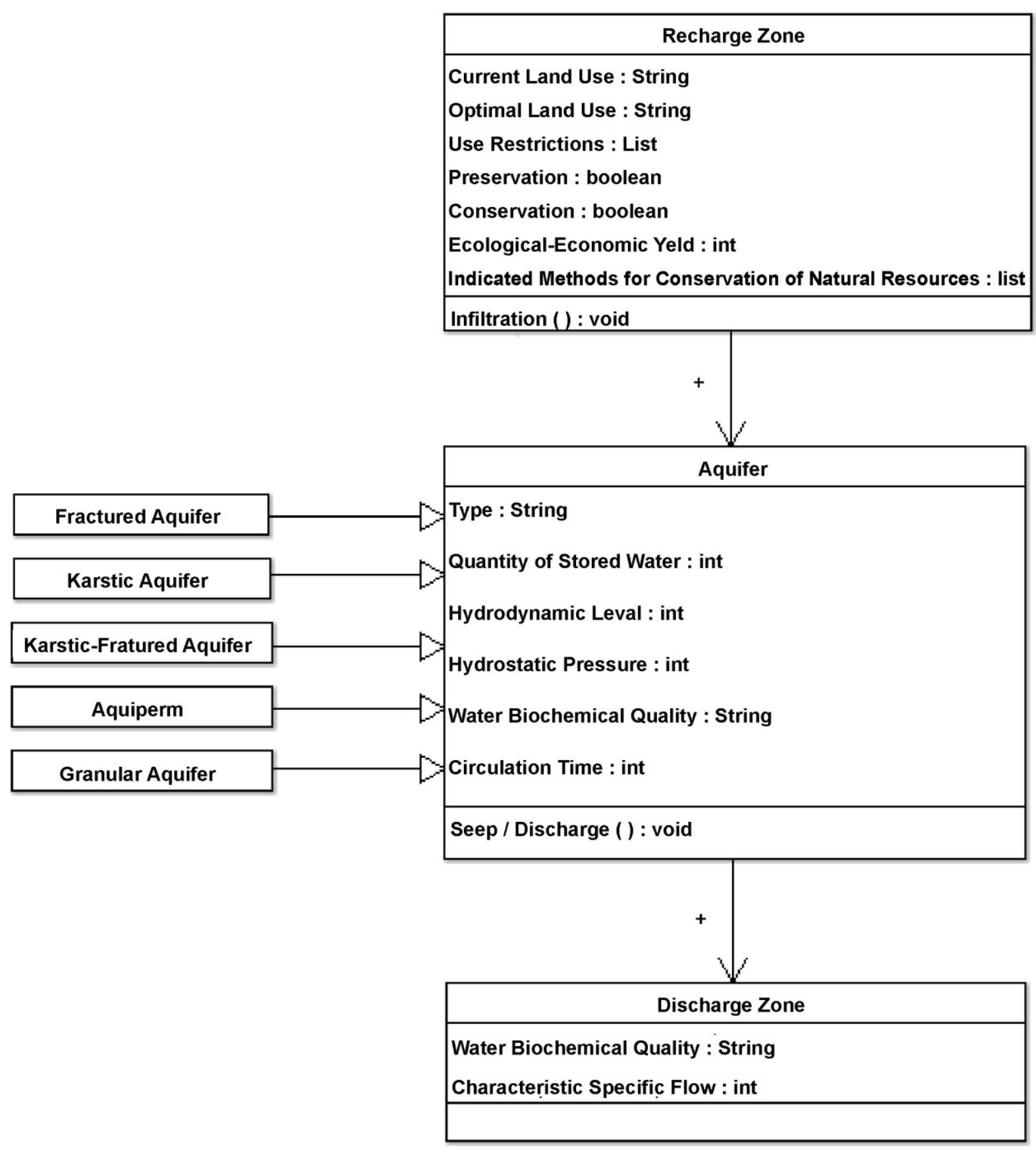

Figure 3 - Context-level UML class diagram. The geological objects (ARZs, aquifer reservoirs and discharge zones) are indicated. Natural and induced processes may alter the energy and mass exchange rates. The safety methods (conservation, optimal soil use, use restrictions, yields, conservation methods) may be programmed. Symbols: int - numerical information; string - textual information; Boolean - logical information; void - functions the value of which is to be filled according to the given instances; list - list of variables.

Source: Translated from Martins Junior et al. (2010) 


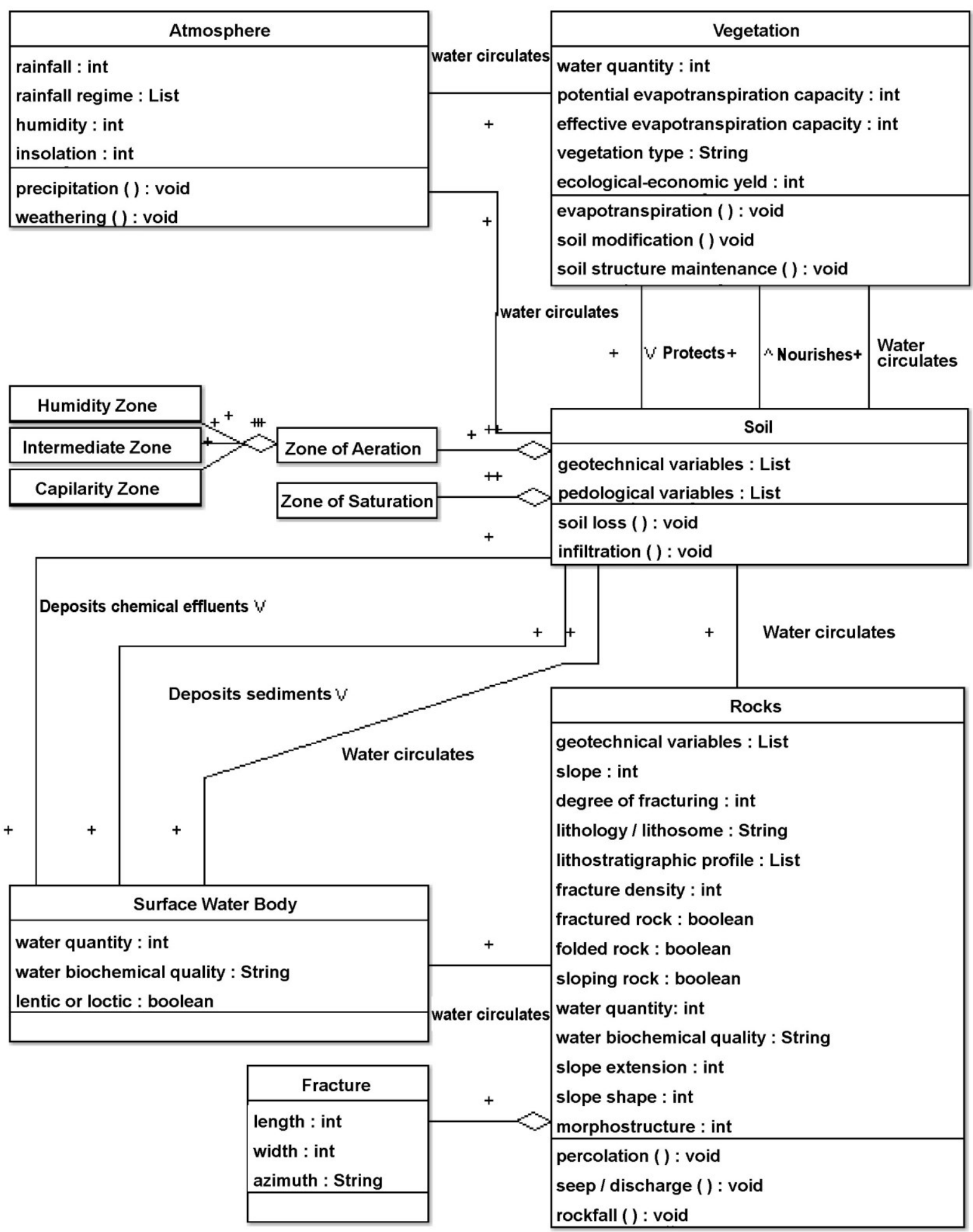

Figure 4 - Context-level UML class diagram, in which the objects and processes are represented according to a view delineated from the environmental systems under consideration. The ORCl organogram (Figure 2) presents itself as a preliminary stage for the formalization of this diagram.

Source: Translated from Martins Junior et al. (2006). 


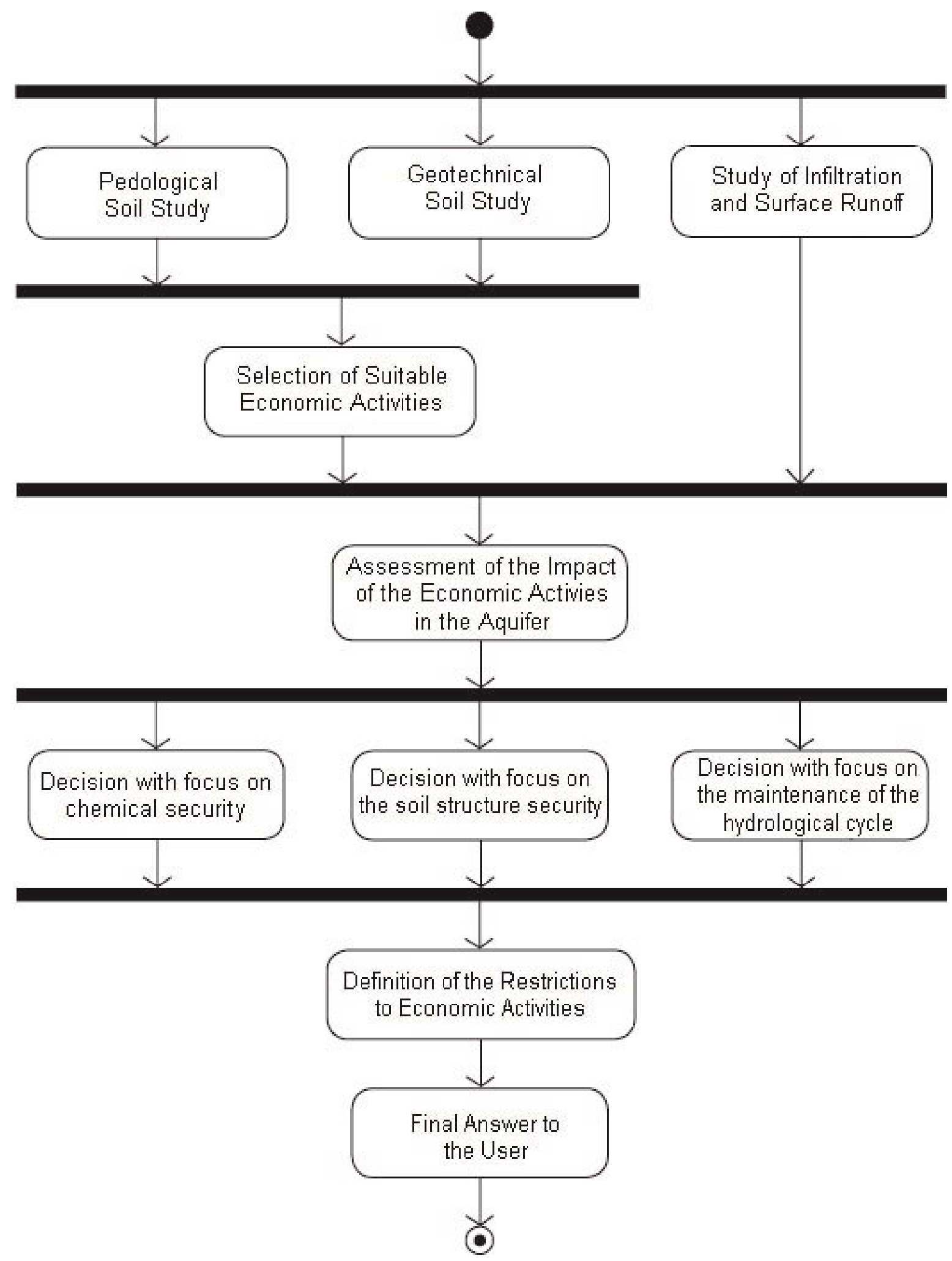

Figure 5 - Context-level activity diagram for environmental management of aquifer recharge. Decision making is aided by considering the limit conditions (preservation area, conservation area, chemical security, mandatory methods of geotechnical security, reciprocal compatibilities and incompatibilities among the various parameters). Source: Translated from Martins Junior et al. (2010). 


\section{INCORPORATING HYDROGEOLOGY INTO THE PUBLIC POLICIES ON ENVIRONMENTAL AND WATER RESOURCES}

\section{Legal Aspects}

The assessment of the possibilities of using knowledge on aquifer recharge and discharge processes in the environmental analyses of public policies requires the characterization of the normative context of such policies. Considering that the instruments used to develop environmental and water resources policies are delimited in a body of legal and infra-legal norms, the dialog between hydrogeology and environmental law becomes vital.

The current Brazilian judiciary system makes few references to the protection of hydrogeological processes. If the norms were to delimit the need for a minimal knowledge on aquifer recharge and discharge in areas of human intervention, the government and the private sector would have to incorporate this topic into their technical work.

The permanent preservation areas (PPAs), which are defined by the Native Vegetation Protection Law (Federal Law $n^{\circ} 12,651$, of 2012), offer partial protection to key areas of the hydrogeological cycle. However, this protection is not specific and therefore not easily adapted to different hydrogeological contexts. The Conama (Conselho Nacional de Meio Ambiente [National Council of Environment]) Resolution $n^{\circ} 369$ of 2006 (when describing studies needed for environmental intervention in urban PPAs) and certain reference terms for environmental impact assessment (EIA) in karst areas demand the specific consideration of hydrogeological processes. However, the incorporation of this legal provision must be founded on social legitimacy and practicality. Otherwise, its application and enforcement may not be effective. Thus, an interesting strategy is to progress from simple use restriction (notdoing) toward sustainable conditions of land use (how to do).

Based on a comparative analysis of laws in several countries, the primary tool for groundwater protection has been the establishment of areas of well protection. The methods vary from the adoption of a fixed circular perimeter to the calculation of the groundwater flow rate (COELHO; DUARTE, 2003, p. 81-82).

The fixed circular perimeter is easily applied. However, it is deficient in that it does not differentiate an increased protection distance in the direction of the 
groundwater flow area and does not consider differences in the groundwater flow rate (USEPA, 1986, p. 9-12; CARVALHO; HIRATA, 2012). Useful inferences to delimit the protection area may be obtained using the aquifer-pumping test or tridimensional numerical/analytical simulation modeling of the drawdown cone relative to the catchment (COELHO; DUARTE, 2003; CARVALHO; HIRATA, 2012). However, in areas with intense well drilling, the drawdown cones may become interconnected, which demands more complex and larger-scale regional studies (CETESB, 2004).

In Brazil, the sources of mineral water (that is, wells or springs with strict economic value, specifically hydromineral or bottling facilities) require studies for the protection of their recharge areas. These studies are detailed in the DNPM [Departamento Nacional de Produção Mineral (National Department of Mineral Production)] Ordinance $n^{\circ} 231$ of 1998 . Analogous to the protection perimeters of wells in European countries, this ordinance prescribes the following classification:

Influence Zone (Zona de influência, ZI) - area relative to the drawdown cone (lowering of the potentiometric surface). The $\mathrm{ZI}$ is the immediate perimeter of the well or spring, where only activities necessary for catchment are allowed. The zone's dimensions are a function of the source's hydrogeological characteristics and how vulnerable the source is to short-term contamination.

Transport zone (Zona de transporte, ZT) - area between the recharge area and the catchment site. This zone determines the time required for a contaminant to travel between the recharge zone and the catchment site. This zone is designed to protect against the more persistent contaminants.

Contribution zone (Zona de contribuição, ZC) - recharge area of the catchment site, which is delimited by the flow lines that converge to this point (equivalent to the effective hydrogeological basin).

The DNPM Ordinance $n^{\circ} 231$ of 1998 details the minimum requirements for the studies but does not provide one single method to delimit the protection areas and does not detail the restrictions that would apply to the protection of these sources. Coelho and Duarte (2003) note that although the protection areas for wells may be based on conventional methods used worldwide, there is no consolidated method that can be safely used to delimit and characterize areas for the protection of springs. For springs, Coelho and Duarte (2003) propose the delimitation of protection 
areas with a distance estimated based on the soil's hydraulic conductivity, which is calculated using analyses of granulometric texture.

Regarding these protection perimeters, USEPA (1986, p. 13) notes that the legal criteria for the protection areas of wells are primarily designed to ensure the water quality of the wells and thus take no significant consideration of ecological impacts, relationships of aquifer discharge with the springs downstream, and multiple water and land uses.

Regarding international law, the United Nations' International Law Commission has been discussing over the last decade how to improve the international agreements that pertain to underground aquifers (UNITED NATIONS, 2008). This discussion has a special relevance for Brazil in connection with the Guarani Aquifer (spread among Brazil, Argentina, Uruguay and Paraguay). Analogous to the difficulties in managing trans-border international aquifers, in Brazil, there is the additional difficulty of managing trans-border aquifers between different states because the Brazilian Federal Constitution determines that states have autonomy over the groundwater within their territorial limits (art. 26, item I). This case is an example of how the discussions pursued on one scale of approach (international) may be used for management on a different scale (interstate). In both approaches, the impact of soil use on the recharge area within the territory of one political entity may compromise the use of the aquifer by the other political entities.

In Brazil, the federal law has no specific rules for groundwater management. Resolutions no. 15/2001, 22/2002, 76/2007 and 92/2008 of the National Council for Water Resources (Conselho Nacional de Recursos Hídricos - CNRH) state the need to include groundwater in the instruments of the Water Resources Policy. However, the resolutions are general and do not specify specific instruments for groundwater management. Nevertheless, groundwater is addressed by general instruments presented in the water resources national law: hydrographic basin master plans, water resources information systems, permits for water use and charges for water use.

An instrument to establish aims and quality criteria related to water bodies has been extended to groundwater by Resolution $n^{\circ} 91$ of the National Council of Water Resources, issued in 2008. However, this resolution is not clear on how to adapt this instrument to the many hydrogeological particularities, such as underground selfpurification, the delimitation of aquifers, aquifuges and aquitards and 
hydrogeochemical influences. Therefore, there are uncertainties regarding the scientific knowledge and local assessment of these characteristics, as well as regarding the use and management demands. Analogously, the criteria for the concession and management of permits to use groundwater remain far from understanding the seasonal volume and recharge of the underground aquifers and, to a greater extent, from understanding how the underground water catchments affect the surface water systems.

Since the updating of the Safe Drinking Water Act in 1986, the US government may delimit areas critical to the protection of aquifers based on specific technical studies (USEPA, 1986). The Brazilian Water Resources National Policy has no similar provision. To close this gap in federal legislation, the states of Minas Gerais, São Paulo, Pernambuco, Pará, Goiás, Rio Grande do Sul, Mato Grosso, Mato Grosso do Sul, Distrito Federal, Acre, Paraná, Rio de Janeiro, Piauí, Amazonas, Rondônia, Tocantins and Roraima have issued their own normative instruments to address groundwater protection, all in similar ways, according to a survey by Toscano et al. (2008).

Regarding the recharge of aquifers for public supply (from wells or resurgences), the previously mentioned state legislation provides the possibility to delimit three zone types:

- Maximum Protection Area - encompasses in full or in part aquifer recharge areas that are highly vulnerable to pollution and that correspond to groundwater deposits essential for public supply.

- Restriction and Control Area - characterized by the necessity to restrict abstraction and by maximum control of established pollution sources and new potentially polluting activities.

- Protection Area of Wells and Other Catchments - includes the minimal distance between wells and other catchments and the respective protection perimeter.

Dutra (2005, p. 30) criticizes the term maximum protection area because the adjective maximum, which was adopted from comparative international laws with the meaning of the maximum area of coverage, is commonly misinterpreted as the area of maximum protection in Brazil. In addition, the Protection Areas of Wells and Other Catchments and the Restriction and Control Areas, which are located closer to the water use points, would generally require more stringent restrictions than the 
Maximum Protection Areas, analogously to the European system (COELHO; DUARTE, 2003; UNITED KINGDOM ENVIRONMENTAL PROTECTION AGENCY, 2008 , p. 80). For the public, this meaning of "maximum protection area" increases the difficulty of its application, because it does not create the impression that it is possible to reconcile sustainable land use with aquifer protection.

Although a large proportion of these state normative instruments of groundwater protection have been sanctioned in Brazil since the 1990s, they have been little used. In São Paulo state, the use of such an instrument has been formally recorded in two areas: Ribeirão Preto (DAEE [Departamento de Águas e Energia Elétrica (Department of Water and Energy Resources)] Ordinance no. 1.594, October 5, 2005; CRH [Conselho Estadual de Recursos Hídricos (State Council for Water Resources)] Deliberation no. 82, June 18, 2008) and Jurubatuba (SÃO PAULO, 2009).

In both cases, these measures were applied after the emergence of serious social conflicts related to groundwater shortages, both in quality and quality. Therefore, it is expected that with increasing demand for water for different activities (rural, industrial and urban) and the associated expansion of potential pollution sources, the protection instruments based on state policies will receive increased use in other Brazilian regions.

\section{Conservation Units in Aquifer Recharge Zones}

In addition to the instruments of the Water and Groundwater Resources Policy, the government has often attempted to protect the recharge of public supply sources by other means, such as using conservation areas. A typical conservation model has been established in Minas Gerais and São Paulo: the spring protection area. In addition, in 1992, Minas Gerais promulgated State Law $n^{\circ} 10,793$, which provides additional rules for the licensing of enterprises in areas that contribute to springs used for public supply, including those outside conservation areas.

The governmental action to protect public supply sources (including legislation and the execution of public policies) must be evaluated alongside other urban planning policies. Goldenstein (BRASIL, 2001, p. 147) states that the environmental zoning and other restrictions in urban expansion areas often refer to a general setting, and the government does not always possess the means to force 
society to obey these rules. A more effective implementation of these instruments depends on a strategic view that includes the relations of politics, power, conflicts and social processes (BRASIL, 2001, p. 152).

An interesting approach has been to include segments of the society in the elaboration, implementation and revision stages of the delimitation of restricted use areas. This inclusion has been implemented using deliberative councils with public participation, public hearings, and other direct and indirect means of participative democracy. In regions where land use is more homogeneous, such as those occupied by agricultural activities, the joining of efforts in relation to common interests is simpler and strongly motivates individuals to value the social capital. Conversely, in areas with a larger diversity of social representations, this endeavor may be more complex because of the more fragmented and diffuse interests (BRASIL, 2001, p.153).

\section{Human Resources}

Although the technical community increasingly considers hydrogeological analyses in the context of water and environmental management to be vital, these analyses are seldom performed. Among the obstacles to the analysis of hydrogeological processes are limited numbers of trained personnel, financial resources and time. Typically, environmental and water resources agencies have few geologists on staff, which is a barrier to the incorporation of geological knowledge in the execution of the instruments of their respective public policies.

A possible explanation of this problem in Brazil is the insufficient number of professionals in the geology and mining engineering fields available to the mining and mineral prospecting labor market (even in the medium term, according to BRASIL, 2011). In addition, the lack of basic training in hydrogeology of the other professionals in the environmental studies teams hinders the initiation of the dialog to solve the previously mentioned problems.

Regarding the studies demanded by the state policies on groundwater resources, the reservation by law of certain technical tasks to hydrogeology professionals (i.e., geologists and mining engineers) deserves attention. The positions related to granting permits for well water use are an example, and the 
assigning of new tasks to these professionals is a potential means to ensure minimal quality in areas in which such knowledge is crucial.

However, in a context in which interdisciplinary approaches are sought, restricting the professional background of the relevant employees may diminish the possibilities of dialog and of providing a more ample interpretation of the environmental problems related to aquifer discharge. The issue of the qualifications of different professionals becomes more complex with the increasing creation of new undergraduate- and graduate-level courses that intersect with the interests of the water resources field and geoscience.

One alternative is to use a minimal set of disciplines (knowledge matrix) instead of demanding a specific graduate diploma, as proposed by the 2005 CONFEA [Conselho Federal de Engenharia e Agronomia (Federal Council of Engineering and Agronomy)] Resolution no. 1,010, which was intended to come into force in Brazil in 2012. However, on May 25, 2012, the CONFEA plenary voted to temporarily suspend this resolution, claiming that additional studies and specifications were required.

\section{Methodological Considerations on Aquifer Recharge Study Techniques}

Despite the issues regarding the availability of trained professionals to address the hydrogeological aspects of the environmental and water resources public policies, such considerations do not exclude the possibility that the currently available methods of hydrogeological studies are not adequate for the contexts in which they are needed to solve environmental and water use issues. Such inadequacy may be the result of a number of issues, such as [1] initially available data, [2] scale(s) of spatial dimension and detail, [3] available professionals, [4] time and financial resources, [5] the required response and [6] the required degree of certainty.

Doubtless, the development and application contexts in which the various approaches and methods of hydrogeological study have been developed originate in the academic setting or research institutes. In such contexts, research is based on funded projects, each of which requires years of development, supported by teams of scholarship awardees in the department's area of expertise. However, due recognition must be given to the practical applications of hydrogeology and hydrology 
in well construction, the drawdown of water tables in mining activities and dam construction.

However, such separation between theoretical and practical development caused Dooge (1988) to recognize the link in the water resources field between a theoretical science (which seeks academic advances in knowledge) and an applied science, which is dedicated to using certain sets of consolidated practices to solve practical problems. Although academic research often focuses on problems with current practical relevance to society, its main goal remains to advance scientific knowledge and to improve the correspondence between models and reality.

Such considerations indicate a need to develop methods to diagnose aquifer recharge and discharge such that their application will be viable in the current context of public policies on environmental and water resources. Such methods may provide key information to aid in decision making based on local instruments (e.g., permits to use water resources, environmental licensing, the allocation of legal preservation areas, deforestation permits) and the development of regional planning (e.g., water resources master plans, municipal master plans, ecological-economic zoning).

Many of the diagnostic and mapping techniques currently applied in environmental and water resources policies exhibit a compartmentalized, static view of the environment. Therefore, groundwater circulation may, by means of aquifer recharge and discharge, reflect the spatio-temporal topological relationships between the elements of the environment, which integrate ecosystems, geosystems and land and water use. Such methodological developments require a good epistemological foundation, with an interdisciplinary focus directed toward water and environmental management.

\section{Strategies to Incorporate Hydrogeological Information in the Public Policies}

In fact, the lack of detailed prior knowledge on the hydrological behavior of a region increases the difficulty of taking preventive measures. Therefore, the technical personnel of the agencies responsible for water resources management reveal insecurity when assessing the economic and social costs and benefits of measures that restrict land use, water use and pollution sources in recharge areas that are relevant to human consumption. Additionally, the limits of governmental resources in terms of personnel and infrastructure for guaranteeing the effectiveness of these 
restrictions must be considered. However, it is largely recognized that the technical possibilities of contaminated soil and aquifer recovery are substantially more costly than restrictive prevention measures (SOUZA, 2010).

Preventive management, such as the identification of areas with increased potential for conflict and areas in which the population is more dependent on the access to groundwater, is another possible strategy. In the US, the government has an institutional policy of identifying priority areas in which the population is more than $50 \%$ dependent on the access to groundwater (USEPA, 2005). These regions are subject to special management procedures, including more detailed studies regarding access to surface sources. In the state of Texas, the areas identified as important aquifers by the communities are managed by aquifer councils (FLORES, 2008), similar to the hydrographic basin committees in conventional water resources legislation.

The location of current and potential water sources for public supply has been identified throughout the United Kingdom (UNITED KINGDOM ENVIRONMENTAL PROTECTION AGENCY, 2008). To protect these perimeters, special spring protection areas were delimited in a conceptual manner. In addition, local (case-bycase) analyses are conducted using weighted checklists to determine whether more detailed studies are required for the application of specific management instruments in the recharge areas (UNITED KINGDOM ENVIRONMENTAL PROTECTION AGENCY, 2008).

Because of the high cost of hydrogeological studies, exploratory methods that perform at least a preliminary characterization of the aquifer recharge processes in a given region may provide the initial information that can be used by environmental and water resources agencies, particularly in developing countries. For example, mapping the relative height to the position of springs (RENNÓ; SOARES, 2003), complemented by mapping the relative height to water courses (RENNÓ et al., 2008; NOBRE et al., 2011), may reveal regions with a predominance of aquifer recharge and discharge.

In the case of instruments that involve regional planning, it is possible to determine the geosystems with the most favorable characteristics for water infiltration using existing maps (soils, slope, lithostratigraphy and rainfall) (BALACHANDAR et al., 2010; VASCONCELOS et al., 2012a). In addition, the analysis of the hydrograms of gauging stations facilitates separating between the components of surface, 
subsurface and groundwater flow, while providing direct information on the behavior of the distinct hydrological dynamics of the basin associated with each station (VASCONCELOS et al., 2013).

Regarding the local action instruments, the environmental impact assessment (EIA), the instrument of the National Environmental Policy in Brazil encompasses rapid diagnostic methods (LOHANI et al., 1997). Rapid diagnostic methods, which are frequently used in environmental impact assessments in riparian ecosystems (BARBOUR et al., 1999; CALLISTO et al., 2002; RODRIGUES, 2008), consist of a set of easily and swiftly applied field procedures and structured spreadsheets. The adaptation of these methods to assess aquifer recharge appears to be an interesting tool for learning and for field application by environmental and water resources professionals (VASCONCELOS et al., 2012b).

With the gradual implementation in Brazil of databases and decision-making support systems in the water resources management agencies, the data related to the permits to use groundwater becomes an important source of information regarding aquifers and their use. One example is SIAGAS (Groundwater Information System - Sistema de Informações de Águas Subterrânea), which contains information on the lithological profiles, hydrogeochemical data and pumping tests of wells with permits granted throughout Brazil (NASCIMENTO et al., 2008).

Notwithstanding SIAGAS's unquestionable usefulness for groundwater management, the statement by Gomes (2008) continues to apply: the use of these data is extremely limited for the modeling of the aquifers to which they refer. After all, these wells were located in areas in which they would have maximum efficiency according to the driller's knowledge and based on field information that is not noted in regional-scale maps (i.e., the wells are not spatially random). In addition, the wells are not homogeneous with respect to depth and other construction characteristics, which increases the difficulty of comparisons and spatial interpolations.

Finally, an increase in the number of telemetric information stations that observe the hydrological cycle, including the installment and maintenance of piezometers, lysimeters, gauging stations and weather stations, would build a knowledge base that is essential to understanding aquifer recharge. Without a sufficient number of stations, integrated studies with these types of measurement, as performed in the US by Ruhl et al. (2002) and Risser et al. (2005), are a distant dream in developing countries. 


\section{FINAL CONSIDERATIONS}

The environmental analyses of aquifer recharge and discharge have demonstrated that this area of research can be a fruitful interdisciplinary field, both for scientific development and for the sustainable management of water and land use. The transdisciplinary dialog presents a number of challenges. However, it promises improved understanding and maturity in the various scientific communities involved. This paper attempted to clarify the relationships between the existing disciplinary knowledge bases and to indicate the potential of new pathways for this interdisciplinary research. Nevertheless, it is recognized that we remain far from achieving a concise and integrated theoretical base that would effectively encompass the knowledge and action dynamics related to the underground aquifers.

The application of computational modeling, as presented in this paper, may be useful for the development of computational models and specialized diagnostic and decision-making support systems for aquifer management. In future studies, a promising way of modeling would involve the creation of more detailed diagrams, while aiming to integrate decision-making support systems and geographic information systems (GIS). This integration may be performed with the aid of the theoretical propositions on geo-ontologies (FONSECA et al., 2000; FONSECA et al., 2006; WANG et al., 2008; among other works), which would connect the existing discussions on the representation, structuring, treatment and management of expert geoscience information. In addition, using the diagrams shown in Figures 3 and 4 , future studies could analyze which classes and treatments deserve the joint treatment of temporal and spatial dynamics (DIAS et al., 2005).

This paper demonstrated that the incorporation of hydrogeological processes into the environmental and water resources policy demands, first of all, that this area of knowledge (hydrogeology) be able to show that it possesses practical methods to solve the environmental issues in question. This demonstration involves the development of methods adapted to the application context and the capacity to transmit and teach this knowledge to professionals from other fields.

Moreover, as a proposition, we conclude that the necessary but careful adaptation of the public policies to address aquifer recharge and discharge demands a common-sense approach based the availability of qualified human resources and 
the application of financial resources with the agility necessary to solve the problems faced. Therefore, the development of methods that can be applied in environmental and water resources management must consider the limitations on time, human resources, information sources and legal possibilities inherent to their respective application contexts.

As a recommendation for the improvement of environmental management, the normative texts of the different spheres (federal, state and municipal) could specify different levels of aquifer protection or conservation. These levels would be defined as the knowledge of the hydrogeology of an intervention site is improved and as the best alternatives for the sustainable use of natural resources are demonstrated in a scientifically credible manner. According to what has been proposed by Johnson et al. (1999) and Dillon (2005), the final goal of a policy that integrates sustainable planning of land and water use would be to quantify the hydrogeological and economic viability of increasing the infiltration in areas of greater potential recharge during the rainy season to guarantee a minimal adequate flow during the dry period in addition to an improvement in water quality. 


\section{RECARGA DE AQUÍFEROS: EPISTEMOLOGIA E INTERDISCIPLINARIDADE}

\section{Resumo:}

As questões ambientais envolvendo recarga e descarga de aquíferos apresentam-se como um desafio para a interdisciplinaridade. Empreende-se, neste artigo, um estudo epistemológico da contribuição de diversas áreas de conhecimento à pesquisa dos processos hidrogeológicos. Apresenta-se, como hipótese, que esse diálogo acena a desenvolvimentos imprescindíveis para a resolução dos problemas ambientais e de uso da água contemporâneos e vindouros. Destarte, propõe-se discutir perspectivas epistemológicas e de gestão de informações que possam contribuir para a melhor caracterização espacial, qualitativa e quantitativa da recarga de aquíferos. São elaboradas modelagens conceituais preliminares demonstrando as possibilidades de articulação interdisciplinar para resolução dos desafios ambientais apresentados. Por fim, são discutidas as possibilidades de incorporação do conhecimento sobre recarga de aquíferos nas políticas públicas de meio ambiente e recursos hídricos.

Palavras-Chave: Aquíferos. Hidrogeologia. Epistemologia. Meio Ambiente. Interdisciplinaridade

\section{RECARGA DE ACUÍFEROS: EPISTEMOLOGÍA E INTERDISCIPLINARIDAD}

\section{Resumen:}

Los temas ambientales relacionados con la recarga y la descarga de acuíferos presentan-se como un desafío interdisciplinario. En este estudio, propone-se una investigación epistemológica acerca de la contribución de las diversas áreas de conocimiento aplicadas a la pesquisa de los procesos hidrogeológicos. Presenta-se, como hipótesis, que esto diálogo señala a desarrollos imprescindibles para la resolución dos problemas ambientales e del uso del agua no presente e en lo futuro. Por lo tanto, propone-se discutir perspectivas epistemológicas y de gestión ambiental que contribuyan para una mejor caracterización espacial, cualitativa y cuantitativa, de la recarga de los acuíferos. Son elaborados modelos conceptuales preliminares demostrando las posibilidades de articulación interdisciplinaria para la resolución de los problemas ambientales presentados. Por último, se discute la posibilidad de incorporar el conocimiento acerca de la recarga de los acuíferos por las políticas públicas de medio ambiente y recursos hídricos.

Palabras-clave: Acuíferos. Hidrogeología. Epistemología. Medio Ambiente. Interdisciplinaridad. 


\section{REFERENCES}

ALMEIDA, M.B.; BAX, M.P. Uma visão geral sobre ontologias: pesquisa sobre definições, tipos, aplicações, métodos de avaliação e de construção [An overview of ontologies: survey on definitions, types, applications, evaluation and building methods]. Ciência da Informação, Brasília, v. 32, n. 3, p.7-20, sep./dec. 2003.

ANDRADE, H.; ALVES, H. M. R.; FERREIRA, E.; MACHADO, R. V.. Geoprocessamento Aplicado a Solos e Meio Ambiente [Geoprocessing Applied to Soils and to the Environment]. Lavras: UFLA/FAEPE, 2006. 58p.

ARRAES, T. M. Proposição de Critérios e Métodos para Delimitação de Bacias Hidrogeológicas [Proposition of Criteria and Methods for the Delimitation of Hydrogeological Basins]. Masters Dissertation. 2008. 125f. Instituto de Geociências [Institute of Geoscience] - UNB. Brasília, DF. 2008.

BALACHANDAR, D.; ALAGURAJA, P.; SUNDARAJ, P.; RUTHARVELMURTHY, K. Application of Remote Sensing and GIS for Artificial Recharge Zone in Sivaganga District, Tamilnadu, India. International Journal of Geomatics and Geosciences, v. 1, n. 1, p. 84-97, 2010.

BARBOUR, M.T.; GERRISTSEN, J.; SNYDER B. D.; STRIBLING, J.B. Rapid Bioassessment Protocols for Use in Streams and Wadeable Rivers: Periphyton, Benthic Macroinvertebrates and Fish. Second Edition. Washington, EPA 841-B-99002. 1999. 339p.

BAUER, H. H. Barriers Against Interdisciplinarity Implications for Studies of Science, Technology, and Society (STS). Science, Technology \& Human Values, v.15, n.1, p. 105-119, Winter, 1990.

BALEK, J. Groundwater Recharge Concepts. In: SIMMERS, I. (org.). Estimation of Natural Groundwater Recharge. Holland: Nato Asi, s. 222. Springer, 1988. 510p.

BOORMAN, D.B., HOLLIS, J.M., LILLY, A. Hydrology of soil types: a hydrologically-based classification of the soils of the United Kingdom. England: Institute of Hydrology, Report no. 126. 1995.

$\mathrm{BOOCH}, \mathrm{G}$; RUMBAUGH, J.; JACOBSON, I. The unified modeling language user guide, UML. 6th printing. Boston: Addison Wesley Publishing Company. 1999.

BRASIL. MMA. Ministério do Meio Ambiente [Ministry of Environment]. Metodologia de Zoneamento Ecológico-Econômico para a Região Sudeste: Transcrição de debates [Methodology of Ecological-Economic Zoning for the Southeastern Region: Transcription of debates]. Brasília. 450p. 2001.

BRASIL. MME. Ministério das Minas e Energia [Ministry of Mines and Energy]. Plano Nacional de Mineração 2030 [National Mining Plan 2030]. Secretaria de Geologia, Mineração e Transformação Mineral [Secretariat of Geology, Mining and Mineral Transformation]. February, 2011. 178p.

CALLISTO, M.; FERREIRA, W.; MORENO, P.; GOULART, M.D.C.; PETRUCCIO, M. Aplicação de um protocolo de avaliação rápida da diversidade de habitats em atividades de ensino e pesquisa (MG-RJ) [The use of a rapid habitat diversity evaluation protocol in education and research activities (MG-RJ)]. Acta Limnol. Bras., v.14, n. 1, p. 91-98, 2002

CARVALHO, A.M.; HIRATA, R. Evaluation of methods for wellhead protection areas 
for the State of São Paulo. Geologia USP, Sér. cient., São Paulo, v. 12, n. 1, p. 5370, Apr. 2012.

CETESB - COMPANHIA AMBIENTAL DO ESTADO DE SÃO PAULO. Sistema de informação para o gerenciamento ambiental dos recursos hídricos subterrâneos na área de afloramento do Aquífero Guarani no Estado de São Paulo [Information systems for environmental management of groundwater resources in the upwelling area of the Guarani Aquifer in São Paulo State]. Secretaria do Meio Ambiente do Estado de São Paulo (Brasil) Secretaria de Meio Ambiente, Saúde Pública e Proteção ao Consumidor do Estado da Baviera (Alemanha) [Secretariat of Environment of São Paulo State (Brazil) Secretariat of Environment, Public Health and Consumer Protection in Bavaria (Germany). São Paulo, April, 2004. 81p.

CHEVALLIER, P. Aquisição e Processamento de Dados [Data Acquisition and Processing]. In: TUCCI, C.E.M. (org.), Hidrologia: Ciência e Aplicação [Hydrology: Science and Application]. Third Edition. ABRH. Federal University of Rio Grande do Sul. Porto Alegre: Editora da Universidade [University's publisher]. 2009.

CLARKE, R.T. Hidrologia Estatística [Statistical Hydrology]. In: TUCCI, C.E.M. (org.), Hidrologia: Ciência e Aplicação [Hydrology: Science and Application]. Third Edition. ABRH. Federal University of Rio Grande do Sul. Porto Alegre: Editora da Universidade [University's publisher]. 2009.

COELHO, V.M.T.; DUARTE, U. Perímetros de Proteção para Fontes Naturais de Águas Minerais [Protection Perimeters for Natural Sources of Mineral Water]. Rev. Águas Subterrâneas, n. 17, p. 77-91, May, 2003.

COLLISCHONN, W and TUCCI, C. E. M. Simulação hidrológica de grandes bacias [Hydrological simulation of large basins]. Revista Brasileira de Recursos Hídricos, v.6, n. 1, p. 95-118, 2001.

CORAZZON, R. What is ontology? [S. I.: s. n.], Available from:

<http://www.formalontology.it/ section_4.htm>. Accessed on: 20 Jul. 2002.

DILLON, P. Future management of aquifer recharge. Hydrogeol J, n. 13, p. 313316, February, 2005. DOI 10.1007/s10040-004-0413-6

DOOGE, J. C. Hydrology in perspective. Hydrological Sciences Journal. Oxford, v.33, n.1, p. 61-85. feb. 1988.

DUTRA, D.A. Plano de Proteção de Aquíferos a partir de Variáveis Ambientais [Aquifer Protection Plan Based on Environmental Variables]. Master's Dissertation. 2005, 101f. UFSM. Santa Maria, 2005.

FERRILL, D.A.;SIMS, D.W.; WAITING, D.J.; MORRIS, A.P.; FRANKLIN, N.M.; SCHULTZ, A.L. Structural framework of the Edwards Aquifer recharge zone in south-central Texas. Geological Society of America. Bulletin; v. 116, n. 3-4, p. 407418, March 2004; DOI: 10.1130/B25174.

FLORES, R.R. Fundamentals of Groundwater Law. State Bar of Texas. Water Rights Boot Camp. May 7, 2008. 16p.

FLYNN R.H.; TASKER, G.D. Generalized Estimates from Streamflow Data of Annual and Seasonal Ground-Water-Recharge Rates for Drainage Basins in New Hampshire. USGS Scientific Investigations Report 2004-5019. New Hampshire. 2004. 72p. 
FLORIANI, D. Disciplinaridade e construção interdisciplinar do saber ambiental [Disciplinarity and the interdisciplinary construction of environmental knowledge]. Revista Desenvolvimento e Meio Ambiente, n. 10, p. 33-37, Jul./Dec. 2004.

FRANCELIN, M. Conceitos, domínios do saber e fronteiras epistemológicas [Concepts, domains of knowledge and epistemological boundaries]. Revista Digital de Biblioteconomia e Ciência da Informação, Brasília, DF, n. 8, v. 2, p. 152-155, 2011.

CETEC-MG - Fundação Centro Tecnológico de Minas Gerais [Technological Center Foundation of Minas Gerais]. II Plano de Desenvolvimento Integrado do Noroeste Mineiro: Recursos Naturais [II Integrated Development Plan of Northwestern Minas Gerais: Natural Resources]. Belo Horizonte: Technological Center Foundation of Minas Gerais. 1981.

GOMES, F.E.M. Geoprocessamento em Ambiente SIG aplicado à Hidrogeologia [Geoprocessing in a GIS Environment, applied to Hydrogeology]. In: FEITOSA, A.C. (org.) Hidrogeologia: conceitos e aplicações [Hydrogeology: concepts and applications]. 3 ed. rev. and exp. Rio de Janeiro: CPRM: LABHID. 2008.

\section{GUERRA, A. T.; GUERRA, A. J. T. Novo Dicionário Geológico-Geomorfológico} [New Geological-Geomorphological Dictionary]. 5th ed. Revised and expanded. Rio de Janeiro: Bertrand Brasil, 2006. 652p.

HOLTSCHLAG, D. J. A generalized estimate of ground-water-recharge rates in the Lower Peninsula of Michigan. U.S. Geological Survey water-supply paper 2437. 1997. 44p.

JACKSON, J.A. Glossary of Geology. Fourth Edition. American Geological Institute. 1997. 754p.

JOHNSON, G.S.; SULLIVAN, W.H.; COSGROVE, D.M.; SCHIMIDT; R.D. Recharge of the Snake River Plain Aquifer: Transitioning from Incidental to Managed. Journal of the American Water Resources. Paper n. 98010, 1999.

JUHASZ, C. E. P.; CURSI, P.R.; COOPER, M.; OLIVEIRA, T.C.; RODRIGUES, R.R. Dinâmica físico-hídrica de uma toposseqüência de solos sob Savana Florestada (Cerradão) em Assis, SP [Soil water dynamics in a toposequence under Savanna Woodland (Cerradão) in Assis, SP, Brazil]. Rev. Bras. Ciênc. Solo, Viçosa, v. 30, n. 3, p. 401-412, June 2006.

LIMA, G.Â.B. Mapa Conceitual como ferramenta para organização do conhecimento em sistemas de hipertextos e seus aspectos cognitivos [Concept maps as a tool for the organization of knowledge in hypertext systems and their cognitive aspects].

Revista Perspectiva em Ciência da Informação, v.9 n.2, p. 134-145, Jul./Dec, 2004.

MARI, H. Metáfora, Metonímia, Denotação e Conotação: a propósito da migração de conceitos [Metaphor, Metonymy, Denotation and Connotation: on concept migration]. In: DOMINGUES, I. (org.) Conhecimento e Transdisciplinaridade II [Knowledge and Transdisciplinarity II]. Belo Horizonte: Editora UFMG, 2005. p. 101-136.

MARQUES, F.S.M. Manual para Levantamento Utilitário do Meio Físico e Classificação da Terra no Sistema de Capacidade de Uso [Manual of Utility Surveys of the Physical Environment and Land Classification in the Use Capacity System]. In: MARTINS JUNIOR, P. P. (coord.). Projeto CRHA - Conservação de Recursos 
Hídricos no âmbito de Gestão Agrícola de Bacias Hidrográficas [CRHA Project - Conservation of Water Resources for Agricultural Management of Hydrographic Basins]. NT-07/2003. Available from: www.crha.cetec.br. Accessed on $05 / 01 / 2013$.

MARTINS JUNIOR, P.P. Fundamentos Conceituais para o Desenvolvimento e a Prática das Geociências Agrárias e Ambientais [Conceptual Bases for Development and Practice in Agricultural and Environmental Geoscience]. A Terra em Revista [The Review on Earth]. No. 4, p.10-15, October, 1998.

MARTINS JUNIOR, P.P. Epistemologia Fundamental: um estudo introdutório sobre a estrutura do conhecimento e a aplicação prática da Epistemologia na pesquisa científica [Environmental Epistemology: an introductory study on knowledge structure and the practical application of epistemology in scientific research]. Belo Horizonte: CETEC Foundation. 2000. 169 p.

MARTINS JUNIOR, P. P. (coord.). Projeto CRHA - Conservação de Recursos Hídricos no âmbito de Gestão Agrícola de Bacias Hidrográficas [CRHA Project Conservation of Water Resources for Agricultural Management of Hydrographic Basins]. 2006. Available from: www.crha.cetec.br. Accessed on 05/01/2013.

MARTINS JUNIOR P.P., ENDO, I., VASCONCELOS, V.V, NOVAES. L. A. d'A, SEQUETTO, M. A. Modelo de Integração de Conhecimentos Geológicos para Auxílio à Decisão sobre uso da Terra em Zonas de Recarga de Aquífero [Aquifer recharge zones and ecologic-economic conservational solutions with agroforestry projects]. Revista Brasileira de Geociências (RBG), v. 36, n. 4, p. 651-662, 2006.

MARTINS JUNIOR, P.P.; CARNEIRO, J. A.; NOVAES, L.A.A.; VASCONCELOS, V.V.; GOMES, L.A.M.; PAIVA, D.A. Modelagem Geo-Ambiental e Interdisciplinar para Ordenamento do Território com Corredores Florestais Ecológico-Econômicos [Geo-Environmental and Interdisciplinary Modeling for Territorial Planning in Areas with Ecological-Economic Forest Corridors]. Revista de Geologia, UFC, v. 21, n. 1, p. 79-97, 2008.

MARTINS JUNIOR, P.P.; CARNEIRO, J.A.; RIBEIRO, S.T.M.; DINIZ, C.P.L.; ABREU JÚNIOR, J.C.; PEREIRA, J.S.; PAIVA, D.A.; BUENO de OLIVEIRA, P.H.

Arquitetura de Conhecimentos em Ecologia-economia para Gestão Ambiental de Bacia Hidrográfica [Knowledge Architecture in Ecology-economy for Environmental Management of Hydrographic Basins]. Belo Horizonte: CETEC Foundation. ACEE Project. 2007. 237p.

MARTINS JUNIOR, P.P.; CARNEIRO, J.A.; KNUPP, V.F.; DINIZ, C.P.L.; ANDRADE, L.M.G.; SCHERRER, L.R.; COUTINHO, V.S.C.; VASCONCELOS, V.V.; NOVAES, L.A.d'A.; OLIVEIRA, L.C.de; FERNANDES, M.M.; SARAIVA, C.C.S.; BAETA, A.M.; BOLIVAR, F.deC.; SANTOS, B.R.V. Instrumentos de Gestão de Recursos Hídricos Subterrâneos entre Bacias que Partilhem Zonas de Recarga de Aqüíferos [Instruments for the Management of Groundwater Resources among Basins that Share Aquifer Recharge Zones]. Belo Horizonte and Ouro Preto: GZRP Project. Final Report. 1 Vol. 2009. 572 p.

MARTINS, JR, P.P., CARNEIRO J.A., ENDO I, MARQUES A.F.S.M.,VASCONCELOS V. V., Novaes L A.A., Gomes, L.A.M., Jano, D.R. Lógica para Modelos de Integração de Conhecimentos para Auxílio à Decisão: Plantios Ecológico-Econômicos em Zonas de Recarga de Aquíferos [Logic Models for Integration of Knowledge to Aid Decisions - Ecologic and Economic Forest 
Plantations in Areas of Aquifer Recharge]. Revista Brasileira de Geociências (RBG), v.40, n. 1, p. 80-98, March, 2010.

MARTINS JUNIOR, P.P.; COUTINHO, C.S.; VASCONCELOS, V.V.; CARNEIRO, J.A.; HADAD, R.M.; JANO, D.R.; MELO, J.W.; ALVARENGA, L.J.; FERNANDES, M.M.; BRITTO, L.O.O.; CLAUS, R.P.; MACHADO, J.L.; HORTA, M.M.X.; CORREA, T.DE O.; ENDO, I. Projeto SACD - Sistemas de Arquitetura de Conhecimentos e de Auxílio à Decisão na Gestão Geo-Ambiental e Econômica de Bacias Hidrográficas e Propriedades Rurais [SACD Project - Knowledge Architecture and Decision-Making Support Systems in the Geo-Environmental Management of Hydrographic Basins and Rural Properties]. Ouro Preto and Belo Horizonte: Fed.Univ.Fed.OP-EM-DEGEO I CETEC Foundation. Final Report, Vol. I. 435p., Vol II. 266p. 2012.

NASCIMENTO, F.M.F.; CARVALHO, J.E.; PEIXINHO; F.C. Sistema de Informações de Água Subterrânea - SIAGAS: histórico, desafios e perspectivas [Groundwater Information System (Sistema de Informações de Água Subterrânea - SIAGAS): history, challenges and perspectives]. In: XV CONGRESSO BRASILEIRO DE ÁGUAS SUBTERRÂNEAS [XV BRAZILIAN CONFERENCE ON GROUNDWATERS], November 11-14, 2008. Natal, RN. Proceedings...., 2008. 18p.

NOVAES, L.F. Modelo para a Quantificação da Disponibilidade Hídrica na Bacia do Paracatu [Model for the Quantification of Water Availability in the Paracatu Basin]. PhD Thesis. 2005. 104p. Federal University of Viçosa, Graduation Program in Agricultural Engineering. Viçosa, 2005.

NAGUETTI, M.; PINTO, E.J.A. Hidrologia Estatística [Statistical Hydrology]. Belo Horizonte: CPRM, 2007. 552p.

NOBRE, A. D., CUARTAS, L. A., HODNETT, M., RENNÓ, C. D., RODRIGUES, G., SILVEIRA, A., WATERLOO, M.; SALESKA, S. Height Above the Nearest Drainage a hydrologically relevant new terrain model. Journal of Hydrology, v. 404, n. 1, p. 13-29, 2011.

OLIVEIRA, A. G. Propriedades Emergentes nas Ciências Exatas [Emergent Properties in Exact Sciences]. Em: DOMINGUES, I. (org.) Conhecimento e Transdisciplinaridade II [Knowledge and Transdisciplinarity II]. Belo Horizonte: Editora UFMG, 2005. p. 101 a 136.

QUEIROZ NETO, J.P. Análise Estrutural da Cobertura Pedológica: uma experiência de ensino e pesquisa [Structural analysis of soil cover: a teaching and research experience]. Revista do Departamento de Geografia, v.15, p. 77-90, 2002.

REGGIANI, P.; SIVALAPAN, M.; HASSANIZADEH, S.M. Conservation equations governing hillslope responses: Exploring the physical basis of water balance. Water Resources Research, v. 36, n. 7, p. 1845-1863, july 2000. American Geophysical Union. Paper number 2000WR900066.

RENNÓ, C. D. e SOARES, J. V. Uso do Índice Topográfico como Estimador da Profundidade do Lençol Freático [Using the Topographic Index to Estimate the Depth of the Water Table]. In: SIMPÓSIO BRASILEIRO DE SENSORIAMENTO REMOTO [BRAZILIAN SYMPOSIUM ON REMOTE SENSING], 11, 2003, Belo Horizonte. Proceedings...: 2579-2588. INPE, São José dos Campos, 2003.

RENNÓ, C. D., NOBRE, A. D., CUARTAS, L. A., SOARES, J. V., HODNETT, M. G., TOMASELLA, J., and WATERLOO, M. J. HAND, a new terrain descriptor using SRTM-DEM: Mapping terra-firme rainforest environments in Amazonia. Remote 
Sensing of Environment, v. 112, n. 9, p. 3469-3481, 2008.

RETALLACK, G.J. Soils of the past: An introduction to paleopedology. USA: WileyBlackwell, 2008. 404p.

RISSER, D.W.; GBUREK, W.J.; FOLMAR, G.J. Comparison of methods for estimating ground-water recharge and base flow at a small watershed underlain by fractured bedrock in the eastern United States. US Department of the Interior, US Geological Survey. 2005. 31p.

ROCHA, G. A.. O grande manancial do Cone Sul [The great spring of the Southern Cone]. Estudos Avançados, v.11 n. 30, p. 191-212, May/Aug, 1997.

ROCHA, P. E. D. Trajetórias e Perspectivas da Interdisciplinaridade Ambiental na Pós-Graduação Brasileira [Trajectories and Perspectives of Environmental Transdisciplinarity in the Brazilian Graduate setting]. Ambiente \& Sociedade, V. 6 , n. 2, p.155-182, Jul./Dec. 2003.

ROCHA, P. E. D. Interdisciplinaridade \& ciências ambientais: a articulação disciplinar e o potencial sócio-participativo da universidade [Interdisciplinarity and environmental science: interdisciplinary articulation and socio-participative potential of the university]. In: ENCONTRO DA ANPPAS (Associação Nacional de Pesquisa e Pós Graduação em Ambiente e Sociedade) [ANPAS (National Association of Research and Graduate Study in Environment and Society] MEETING], 2, 2004, Proceedings..., Indaiatuba (SP):ANPPAS, 2004. Available from: <http://www.anppas.org.br/ >. Accessed on: Jul. 2007.

RODRIGUES, A.S.L. Adequação de um protocolo de avaliação rápida para o monitoramento e avaliação ambiental de cursos d'água inseridos em campos rupestres [Adaptation of a rapid-assessment protocol for the monitoring and environmental evaluation of water courses located in rocky fields]. Master's Dissertation. 2008, 118p. UFOP - DEGEO. Graduation Program in Crustal Evolution and Natural Resources, Minas Gerais. 2008.

ROSA, E. U. Desenvolvimento de Procedimentos Computacionais para Integração de Sistemas de Informação Geográfica com Modelos Hidrológico Chuva-Vazão em Bacias Urbanas [Development of Computational Procedures for the Integration of Geographic Information Systems with Rainflow Hydrological Models in Urban Basins]. Master's Dissertation. 2002, 134p. [Rio de Janeiro]., M.Sc. Computer Engineering - Geothematic Concentration Area. UERJ. 2002.

ROSA FILHO, E.F.; HINDI, E.C.; ROSTIROLLA, S.P.; FERREIRA, F.J.F.; BITTENCOURT, A.V.L. Sistema Aquifero Guarani - considerações preliminares sobre a influência do Arco de Ponta Grossa no fluxo das águas subterrâneas [Guarani Aquifer System - preliminary considerations regarding the influence of the Ponta Grossa Arch on groundwater flow]. Rev. Águas Subterrâneas, n. 17, p. 91112, May, 2003.

RUHL, J.F.; KANIVETSKY, R.; SHMAGIN, B. Estimates of recharge to unconfined aquifers and leakage to confined aquifers in the seven-county metropolitan area of Minneapolis-St. Paul, Minnesota. Water Resources Investigations Report. United States Geological Survey, (4092), 2002.

SANTOS, L.J.C. Contribuição da Análise Estrutural da Cobertura Pedológica ao Desenvolvimento da Ciência do Solo [Structural Analysis Contribution of the 
Pedological Cover to Soil Science Development]. Revista Raega, Curitiba, n. 4, p. 131-138, 2000.

SANTOS, R.D.; LEMOS, R.C.; SANTOS, H.G.; KER, J.C.; ANJOS, L.H.C. Manual de Descrição e Coleta de Solo no Campo [Field Manual of Soil Description and Sampling] - 5th. ed. Sociedade Brasileira de Ciência do Solo [Brazilian Society of Soil Science] (SBCS). SBCS-27. Viçosa: SBCS, 2005. 92p.

SCANLON, B.R.; HEALY, R.W.;COOK, P.G. Choosing appropriate techniques for quantifying groundwater recharge. Hydrogeology Journal, v. 10, p. 18-39, January, 2002. DOI 10.1007/s10040-0010176-2

SCHREIBER, G.; AKKERMANS, H.; ANJEWIERDEN, A.; HOOG, R.; SHADBOLT, N.; VELDE, W.V.; WIELINGA, B. Knowledge engineering and management: the CommonKADS methodology. Boston: Bradford BooK, The MIT Press, Massachusetts Institute of Technology/Cambridge, London. 1999.

SCHRÖDER, B. Pattern, process, and function in landscape ecology and catchment hydrology - how can quantitative landscape ecology support predictions in ungauged basins (PUB)? Hydrol. Earth Syst. Sci. Discuss., v. 3, p. 1185-1214, 2006.

SECRETARIA DE ESTADO DO MEIO AMBIENTE.SECRETARIA DE ESTADO DE SANEAMENTO E ENERGIA. São Paulo. Projeto Jurubatuba: restrição e controle de uso de água subterrânea [Jurubatuba Project: groundwater use restriction and control]. Cadernos do Projeto Estratégico Aquíferos [Notes on the Strategic Aquifers Project]; n. 01. São Paulo: DAEE/IG. 2009. 109 p.

SILVA, M.L.N. Conservação do Solo e da Água [Soil and Water Conservation]. Federal University of Lavras, Faepe, 2002. 59p.

SILVEIRA, A.L.L. Ciclo Hidrológico e Bacia Hidrográfica [Hydrological Cycle and Hydrographic Basin]. In: TUCCI, C.E.M. (org.), Hidrologia: Ciência e Aplicação [Hydrology: Science and Application]. Third Edition. ABRH. Federal University of Rio Grande do Sul. Porto Alegre: Editora da Universidade [University's publisher]. 2009.

SILVEIRA, A.L.; LOUZADA, J.A.;BELTRAME, L.F. Infiltração e Armazenamento no Solo [Soil Infiltration and Storage]. In: TUCCI, C.E.M. (org.), Hidrologia: Ciência e Aplicação [Hydrology: Science and Application]. Third Edition. ABRH. Federal University of Rio Grande do Sul. Porto Alegre: Editora da Universidade [University's publisher]. 2009.

SIMMERS, I. Estimation of Natural Groundwater Recharge. Holland: Nato Asi, s. 222. Springer, 1988. 510p.

SIVALAPAN, M. Pattern, Process and Function: elements of a unified theory of hydrology at the catchment scale. In: ANDERSON, M.G (Editor). Encyclopedia of Hydrological Sciences. Ed. John Wiley \& Sons Ltda. p. 193-219, 2005

SMITH, M.K.; WELTY, C.; MCGUINNESS, D.L. OWL Web Ontology Language Guide. W3C Recommendation 10 February. Available from http://www.w3.org/TR/2004/REC-owl-guide-20040210/. Copyright @ 2004 W3C $\circledast$ (MIT, Ercim, Keio).

SOARES, A.P. Variabilidade espacial no Sistema Aquífero Guarani: controles estratigráficos e estruturais [Spatial variability in the Guarani aquifer system: stratigraphic and structural controls]. PhD Thesis. 2008. 196f. Federal University of Rio Grande do Sul. Institute of Geoscience. Graduation Program in Geoscience. 
2008.

SOUZA, L.C. A Efetividade da Proteção das Águas Subterrâneas no Brasil [Effectiveness of Groundwater Protection in Brazil]. In: $8^{\circ}$ CONGRESSO BRASILEIRO DO MAGISTÉRIO SUPERIOR DA ASSOCIAÇÃO DOS PROFESSORES DE DIREITO AMBIENTAL DO BRASIL [8 $8^{\text {th }}$ BRAZILIAN CONFERENCE OF HIGHER EDUCATION PROFESSORS OF THE ASSOCIATION OF ENVIRONMENTAL LAW PROFESSORS OF BRAZIL] - APRODAB and $1^{\circ}$ CONGRESSO DE DIREITO AMBIENTAL DA PUC-RIO $\left[1^{\text {st }}\right.$ ENVIRONMENTAL LAW CONFERENCE OF THE PUC-RIO]. Rio de Janeiro, 2010. Proceedings... Rio de Janeiro: PUC-RIO, 2010, 20p.

SOUZA, E.R.; FERNANDES, M.R. Sub-bacias hidrográficas: unidades básicas para o planejamento e a gestão sustentáveis das atividades rurais [Hydrographic subbasins: basic units for sustainable planning and management of rural activities]. Informe Agropecuário [Agricultural Report]. Manejo de Microbacias [Microbasin Management]. v. 21, n. 207, p. 15-20, nov/dec, 2000.

SOWA, J.F.; MOULIN, B.; MINEAU, G.W. Conceptual Graphs for Knowledge Representation, Lecture Notes in AI 699. Berlin: Springer-Verlag. 1993.

SOWA, J.F. Knowledge Representation: Logical, Philosophical, and Computational Foundations. Pacific Grove: Brooks Cole Publishing Co., CA. 2000. 594p.

STOREY, M.A.; MUSEN, M.; SILVA, J.; BEST, C.; ERNST, N.; FERGERSON, R.; NOY, N. Jambalaya: Interactive visualization to enhance ontology authoring and knowledge acquisition in Protege. In: WORKSHOP ON INTERACTIVE TOOLS FOR KNOWLEDGE CAPTURE, Victoria, B.C. Canada, October, 2001, Annals..., Victoria: University of Southern California, 2001.

STOREY, M.A.; BEST, C.; MICHAUD, J.; RAYSIDE, D.; LITOIU, M.; MUSEN, M. SHRIMP views: an interactive environment for information visualization and navigation. In: PROCEEDINGS OF THE INTERNATIONAL CONFERENCE ON HUMAN FACTORS IN COMPUTER SYSTEMS (CHI 2002), Minneapolis, Minnesota, USA, April 20-25, Proceedings..., Minneapolis: SIGCHI, pp. 520-521, 2002.

SUI, D. Z.; MAGGIO, R. C., Integrating Gis With Hydrological Modeling Practices, Problems, And Prospects, International Journal of Computers, Environment, and Urban Systems, Elsevier Science Publishers, Texas, v. 23, n. 1, p. 35-51, 1999.

TOSCANO, G.L.G.; SANTOS, K.M.; ALMEIDA, C.N.; SILVA, T.C. 2008. Uma análise sintética sobre a legislação de proteção das águas subterrâneas no Brasil [A synthetic analysis of the groundwater protection legislation in Brazil]. In: SIMPÓSIO DE RECURSOS HÍDRICOS DO NORDESTE [SYMPOSIUM ON HYDRIC RESOURCES OF THE NORTHEAST], 9, Salvador, Bahia, 2008.. Proceedings... Salvador: ABRH. 2008

TUCCI, C. E. M. Regionalização de Vazões [Flow regionalization]. Porto Alegre: Ed. Universidade: UFRGS, 2002. 256 p.

TUCCI, C.E.M. (org.) Hidrologia: Ciência e Aplicação [Hydrology: Science and Application]. Third Edition. ABRH. Federal University of Rio Grande do Syl. Porto Alegre: Editora da Universidade [University's publisher]. 2009. 
UNITED KINGDOM ENVIRONMENT AGENCY. Groundwater Protection: Policy and practice. Edition 1. Part 4 - Legislation and Policies. England. 2008. 96p. Available from http://publications.environmentagency.gov.uk/PDF/GEHO0708BOGU-E-E.pdf, accessed in December 2012.

UNITED NATIONS. Draft articles on the Law of Transboundary Aquifers. Official Records of the General Assembly, Sixty-third Session, Supplement n. 10 (A/63/10). 2008. 10p

\section{USDA - UNITED STATES DEPARTMENT OF AGRICULTURE. National Soil}

Survey Handbook. Title 430-VI. Natural Resources Conservation Service, Washington, DC. 2001. Available from http://soils.usda.gov/technical/handbook/, accessed in March 2006.

USEPA - UNITED STATES ENVIRONMENTAL PROTECTION AGENCY. Guidelines for Ground-Water Classification under de EPA Ground Water Protection Strategy. EUA/EPA. Office of Ground Water Protection. 1986. 385p.

USEPA - UNITED STATES ENVIRONMENTAL PROTECTION AGENCY. Sole Source Aquifer Protection Program. National Summary of Sole Source Aquifer Designations. 2005.

VASCONCELOS, V.V. MARTINS JUNIOR, P.P., NOVAES, L. A. d'A. 2005. Sistema Inteligente de Apoio à Decisão em Gestão de Recursos Hídricos e Projetos Agrícolas [Intelligent Decision-Making Support System for the Management of Water Resources and Agricultural Projects], In: SIMPÓSIO BRASILEIRO DE RECURSOS HÍDRICOS [BRAZILIAN SYMPOSIUM ON WATER RESOURCES], 16, João Pessoa, Paraíba, 2005, Proceedings..., João Pessoa: ABRH, 2005. 20 p.

VASCONCELOS, V.V.; MARTINS JUNIOR, P.P.; JANO, D.R. Arquitetura de Conhecimentos sobre Sistemas Aquiferos [Knowledge Scheme of Aquifer Systems]. Revista Digital de Biblioteconomia e Ciência da Informação. Campinas, v.9, n.1, p.184-208, Jul./Dec. 2011.

VASCONCELOS, V.V.; MARTINS JUNIOR, P.P. e HADAD, R. M. Metodologia Cartográfica para Favorabilidade de Recarga de Aquíferos [Cartographic Methodology for Aquifer Recharge Favorability]. 12p. In: MARTINS JUNIOR, P.P. (coord.) Projeto SACD - Sistemas de Arquitetura de Conhecimentos e de Auxílio à Decisão na Gestão Geo-Ambiental e Econômica de Bacias Hidrográficas e Propriedades Rurais [SACD Project - Knowledge Architecture and Decision-Making Support Systems in the Geo-Environmental Management of Hydrographic Basins and Rural Properties]. Ouro Preto and Belo Horizonte: Fed.Univ.Fed.OP-EM-DEGEO / CETEC Foundation. 266p. 2012a.

VASCONCELOS, V.V.; MARTINS JUNIOR, P.P. e HADAD, R. M. Metodologia para Diagnóstico Expedito de Áreas de Recarga de Aquíferos [Methodology for Rapid Diagnosis of Aquifer Recharge Areas]. 28p. In: MARTINS JUNIOR, P.P. (coord.) Projeto SACD - Sistemas de Arquitetura de Conhecimentos e de Auxílio à Decisão na Gestão Geo-Ambiental e Econômica de Bacias Hidrográficas e Propriedades Rurais [SACD Project - Knowledge Architecture and Decision-Making Support Systems in the Geo-Environmental Management of Hydrographic Basins and Rural Properties]. Ouro Preto and Belo Horizonte: Fed.Univ.Fed.OP-EM-DEGEO / CETEC Foundation. 266p. 2012b.

VASCONCELOS, V.V.; MARTINS JUNIOR, P.P. e HADAD, R. M. Estimation of flow 
components by recursive filters: case study of Paracatu River Basin (SF-7), Brazil. Geologia USP, Série Científica [USP Geology, Scientific Series] [online]. v.13, n.1, p. 3-24, 2013. Available from:

http://ppegeo.igc.usp.br/scielo.php?script=sci arttext\&pid=S1519-

$\underline{874 X 2013000100001 \& \operatorname{lng}=p t \& n r m=i s o \& t \operatorname{lng}=e n}$, accessed on 05/01/2013.

Article:

Received: November, 2012

Accepted: September, 2013 